\title{
Review: Aplikasi Material Komposit Berbasis Kitosan sebagai Bahan Kemasan Makanan
}

\author{
Shalahudin Nur Ayyubi ${ }^{1}$, Kusmiyati ${ }^{2 *}$, Aprilina Purbasari ${ }^{1}$, Wahyu Zuli Pratiwi ${ }^{1}$ \\ ${ }^{1}$ Departemen Teknik Kimia, Fakultas Teknik, Universitas Diponegoro, \\ Jl. Prof. Soedarto, SH, Kampus UNDIP Tembalang, Semarang, Indonesia 5027 \\ ${ }^{2}$ Departemen Teknik Industri, Fakultas Teknik, Universitas Dian Nuswantoro, \\ Jl. Imam Bonjol No.207, Pendrikan Kidul, Kec. Semarang Tengah, Semarang, Indonesia 50131
}

\begin{abstract}
Abstrak
Perhatian terhadap biopolimer pada zaman sekarang semakin meningkat disebabkan oleh banyaknya bahan kemasan berbasis plastik yang tak dapat terurai secara alami. Kitosan dapat dijadikan sebagai alternatif pengganti polimer sintetik untuk material yang baru. Untuk melihat kesesuaian suatu material sebagai bahan pengemas makanan, perlu dilakukan kajian terhadap sifat mekanik dan permeabilitas. Sifat mekanik digunakan untuk memprediksi perilaku film selama pengangkutan, penanganan dan penyimpanan makanan kemasan. Sifat penghalang memainkan peran kunci dalam menjaga kualitas produk makanan. Sifat mekanik dan permeabilitas film kitosan murni cocok untuk kemasan makanan dan kemasan aktif. Sifat-sifat ini dapat dimodifikasi dengan menggabungkan kitosan dengan material lain seperti pemplastis, polisakarida, protein dan lipid. Kombinasi ini menyesuaikan sifat-sifat hasil polimer akhir untuk memperpanjang masa simpan makanan, sambil mempertahankan sifat kualitas makanan dan kemampuan terurai secara alami dari polimer tersebut. Kitosan juga menunjukkan aktivitas antimikroba yang baik terhadap berbagai macam jamur makanan, ragi, dan bakteri gram negatif dan gram positif. Sifat antimikroba ini telah menjadikan kitosan sebagai polimer untuk pengembangan kemasan aktif dengan kemampuan menghambat pertumbuhan mikroorganisme serta meningkatkan keamanan pangan.
\end{abstract}

Kata kunci: plastik biodegradable; kitosan; biopolimer; material komposit; kemasan makanan aktif

\begin{abstract}
[Title : Review: the application of chitosan-based composite materials as food packaging] The attention to biopolymers today is increasing due to the large number of plastic-based packaging materials that can decompose naturally. Chitosan can be used as an alternative to synthetic polymers for new materials. To see the suitability of a material as a food packaging material, it is necessary to study its mechanical properties and permeability. Mechanical properties are used to predict behaviour during film transport, handling, and storage of packaged foods. Barrier properties play a key role in maintaining the quality of food products. The mechanical properties and permeability of pure chitosan films are suitable for food packaging and active packaging. These properties can be regulated by combining chitosan with other materials, such as plasticizers, polysaccharides, proteins, and lipids. This combination adapts the properties of the final polymer yield to extend the shelf life of the food while maintaining the food quality and biodegradability of the polymer. Chitosan also exhibits good antimicrobial activity against various fungi, yeasts, gram-negative and gram-positive bacteria. This antimicrobial property has made chitosan a polymer for developing active packaging to inhibit microorganisms and improve food safety.
\end{abstract}

Keywords: biodegradable plastic; chitosan; biopolymer; composite material; active food packaging

\footnotetext{
*) Penulis Korespondensi.

E-mail: kusmiyati@dsn.dinus.ac.id
}

\section{Pendahuluan}

Selama beberapa dekade terakhir, semakin banyak minat untuk mencari alternatif pengganti plastik berbasis minyak bumi karena masalah lingkungan. Sampah plastik 


\section{TEKNIK, 42 (3), 2021, 336}

menjadi masalah yang serius. Salah satu pendekatan untuk memecahkan masalah ini adalah dengan menggunakan bahan yang dapat terurai secara hayati daripada polimer yang tidak dapat diperbarui dalam kemasan. Bahan-bahan ini berpotensi mengurangi pencemaran lingkungan dengan menurunkan limbah padat. Sejak beberapa tahun lalu, aplikasi film sintetis dalam kemasan makanan telah berkembang pesat.

Polimer sintetik asal petrokimia seperti polietilen tereftalat, polivinilklorida, polietilen, polipropilen, polistiren, dan poliamida digunakan sebagai bahan pengemas karena memiliki sifat yang optimal, seperti sifat mekanik yang baik dan penghalang yang baik terhadap beberapa senyawa seperti oksigen, karbon dioksida, uap air dan senyawa aroma. Selain itu, polimer sintetik yang berasal dari petrokimia dapat diperoleh dengan biaya rendah. Namun, jenis polimer ini memberikan kerugian besar yaitu tidak dapat terurai secara alami. Pengembangan polimer biodegradable menjadi kemasan pangan ramah lingkungan merupakan salah satu strategi untuk meminimalkan masalah penumpukan plastik di lingkungan. Saat ini, penggantian secara menyeluruh polimer berbasis petrokimia dengan polimer biodegradable tidak mungkin dilakukan. Tetapi biopolimer baru yang dikembangkan dapat menjadi solusi untuk penggantian sebagian dari polimer nonbiodegradable tergantung pada aplikasinya karena kemampuannya dalam mencegah kehilangan kelembaban, hilangnya aroma, transportasi zat terlarut, penyerapan air dalam matriks makanan atau penetrasi oksigen (Cazón dkk., 2017; Kerch dan Korkhov, 2011)

Selain itu, bahan-bahan ini mendapat perhatian khusus dalam pengawetan makanan. Mereka menawarkan kemungkinan untuk memperpanjang umur simpan melalui kontak langsung dengan makanan segar atau olahan (Elsabee dan Abdou, 2013). Bahan baku yang dipelajari untuk mengembangkan biopolimer baru berasal dari sumber alam yang terbarukan seperti protein, lipid, polisakarida dan semua kombinasinya. Kadang-kadang, penggabungan aditif digunakan untuk memperbaiki sifatsifat film (Cazón dkk., 2017).

Kitosan adalah salah satu polisakarida yang paling banyak dipelajari. Lebih dari 9000 artikel tentang film kitosan telah diterbitkan sejak 2016 hingga awal tahun 2019 (ScienceDirect ${ }^{\circledR}$ ). Kitosan telah mendapat perhatian untuk aplikasi komersialnya di industri biomedis, makanan, dan kimia karena nonantigenik, tidak beracun, biodegradable, biokompatibel, bio-fungsional dan sifat anti mikroba (Aider, 2010; Cazón dkk., 2017). Kitosan berasal dari udang telah diakui US Food and Drug Administration (FDA) sebagai produk yang aman berdasarkan prosedur ilmiah untuk digunakan dalam makanan secara umum sejak tahun 2001 (S. H. Kim dkk., 2007).

doi: 10.14710/teknik.v42i3.36499

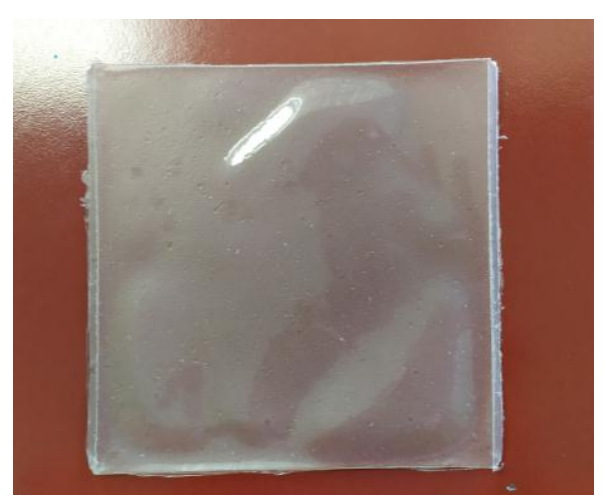

Gambar 1. Sampel plastik biodegradable campuran kitosan/pati singkong/PVA yang dibuat dari larutan kitosan dengan berat molekul dalam kisaran 100-300 $\mathrm{kDa}$ dan dengan $2 \%(\mathrm{v} / \mathrm{v})$ asam asetat.

Selain itu, kitosan merupakan polisakarida yang paling melimpah kedua di dunia dan dapat diperoleh dari banyak sumber terbarukan, terutama limbah dari kerang industri. Terlebih di Indonesia yang merupakan negara maritim yang kaya akan aneka jenis hewan laut jenis crustacea yang dapat dimanfaatkan sebagai bahan baku kitosan. Oleh karena harganya tidak mahal dan tersedia secara dalam jumlah yag banyak. Hal ini sangat penting karena bahan biaya yang rendah dapat meminimalkan biaya produksi (Aider, 2010; Cazón dkk., 2017; K. M. Kim dkk., 2006).

Sifat pembentuk film kitosan memungkinkan produksi film dan bahan pelapis dengan sifat mekanik yang baik, permeabilitas selektif terhadap $\mathrm{CO}_{2}$ dan $\mathrm{O}_{2}$ dan sifat antimikroba untuk diterapkan langsung pada makanan untuk meningkatkan keamanan pangan dan umur simpan. Gambar 1 menunjukkan film kitosan yang diperoleh di sebuah laboratorium.

Beberapa strategi telah diusulkan untuk meningkatkan sifat fungsional film kitosan, seperti modifikasi derajat deasetilasi, $\mathrm{pH}$, jenis pelarut dan pencampuran dengan plasticizer atau komponen lain seperti protein atau polisakarida (Elsabee dan Abdou, 2013).

Pada review kali ini akan dibahas tentang potensi dan kinerja material kitosan yang dikompositkan dengan material lain seperti pemplastis (platsticizer), protein, polisakarida dan lipid terutama berfokus pada pembahasan sifat mekanik, sifat penghalang, dan sifat anti mikroba film kitosan

\section{Metode Penelitian}

Untuk mencapai tujuan penulisan artikel ilmiah ini, dilakukan penelusuran literatur menggunakan berbagai sumber. Pencarian sumber pustaka utama dilakukan melalui mesin pencarian di website Mendeley. Sebagian besar referensi dipilih dari artikel yang terbit 


\section{TEKNIK, 42 (3), 2021, 337}

di jurnal internasional terindeks. Keseluruhan rujukan merupakan rujukan dari sumber primer. Penelusuran literatur menggunakan kata kunci "biocomposite", "chitosan", "biopolymer", dan "active food packaging".

\section{Hasil dan Pembahasan \\ 3.1 Film Kitosan dan Sifatnya Sebagai Pelapis atau Coating}

Kitosan adalah turunan dari kitin, salah satu bahan yang paling alami yang melimpah di dunia. Setelah selulosa, kitosan merupakan biopolimer yang paling banyak kedua akan kelimpahannya. Kitin diisolasi dari limbah krustasea (udang dan kepiting). Sumber kitin atau kitosan alternatif adalah jamur, ragi, protozoa, mikroalga, dan serangga, meskipun aplikasi industrinya terbatas (Chenite dkk., 2001; Kerch dan Korkhov, 2011; Rinaudo, 2006; Van Den Broek dkk., 2015).

Kitin diperoleh dengan dikomplekskan dengan zat lain seperti protein dan mineral. Untuk memperoleh kitin perlu dilakukan pengolahan dengan pengolahan asam (dekalsifikasi) dilanjutkan dengan pengolahan basa (deproteinasi), dan terakhir tahap dekolorisasi. Untuk menyiapkan kitosan dilakukan proses deasetilasi terhadap kitin. Kitin sangat banyak mengandung asetil dan tidak larut dalam air. Untuk mendapatkan kitosan diperlukan kadar $\mathrm{N}$-asetilasi lebih rendah dari 50\%, tergantung pada asal polimer. Oleh karena itu, kitosan merupakan turunan kitin dengan basa deasetilasi.

Kitosan tidak mengidentifikasi satu zat unik, tetapi digunakan untuk menggambarkan rangkaian polimer dengan berat molekul rata-rata yang berbeda $(50-2000$ kDa) dan derajat deasetilasi (40-98\%). Dalam keadaan padat, kitosan merupakan semi-kristal dan dengan sifat kelarutan dalam asam organik encer seperti asam asetat. Rentang yang berbeda pada berat molekul dan derajat deasetilasi tergantung pada kondisi reaksi deasetilasi. Konsentrasi alkali, waktu inkubasi, rasio kitin terhadap alkali, suhu, atmosfer, jenis sumber kitin (termasuk jenis polimorf), ukuran partikel dan heterogen/homogen $\mathrm{N}$ deasetilasi mempengaruhi sifat film dari kitosan.

Mengenai kelarutan kitosan untuk mendapatkan larutan film, hal itu tergantung pada derajat deasetilasi, distribusi gugus asetil di sepanjang rantai utama, berat molekul dan sifat asam yang digunakan. Pada konsentrasi di atas $>2 \%$ (b/b) kitosan, larutan menjadi sangat kental, sehingga sulit untuk dimanipulasi solusinya (Leceta dkk., 2013; Morgado dkk., 2011; Rinaudo, 2006; Van Den Broek dkk., 2015).

Telah dikembangkan sistem pelarut yang baru, sebagai alternatif untuk larutan asam larutan untuk melarutkan kitosan, menggunakan sistem basa (alkali/urea) untuk melarutkan kitosan melalui metode pembekuan-pencairan, pelarut yang sebelumnya telah dikembangkan untuk melarutkan selulosa (L. Zhang dkk., 2005). Pelarutan lengkap kitosan berbobot molekul sedang $(157,5 \mathrm{kDa})$ dan kitosan berbobot molekul rendah $(53,4 \mathrm{kDa})$ dalam larutan $\mathrm{NaOH} /$ urea setelah enam atau lima siklus perlakuan beku-cair telah dilaporkan berhasil (W. Zhang \& Xia, 2014). Alternatif lain untuk Sistem $\mathrm{NaOH} /$ urea menggunakan $\mathrm{LiOH}$ atau tiourea. Kitosan berhasil dilarutkan dalam larutan berair $\mathrm{LiOH} /$ urea (Fan dan $\mathrm{Hu}, 2009$ ) dan larutan berair $\mathrm{NaOH} /$ tiourea (Almeida dkk., 2010).

Bagaimanapun, untuk mengembangkan film atau pelapis untuk kemasan makanan, larutan kitosan dengan media yang sedikit asam seperti asam asetat tetap sebagai metode yang paling banyak digunakan. Di antara semua metode untuk mendapatkan film berbasis kitosan, metode casting adalah yang paling sering digunakan.

Dengan menggunakan metode alkali/urea, diperlukan langkah regenerasi film dengan cara perendaman cetakan dengan larutan pembentuk film ke dalam bak koagulasi (Almeida dkk., 2010). Kemudian, film yang diregenerasi dikeringkan untuk mengelupas cetakan. Pembentukan film terjadi karena mempertahankan belitan rantai dan interaksi antarmolekul yang terbentuk selama proses pengeringan, seperti elektrostatik dan ikatan hidrogen (Muxika dkk., 2017). Kitosan bukan termoplastik, oleh karena itu, tidak dapat diekstrusi atau dicetak dan film tidak dapat disegel panas. Hal ini mendegradasi sebelum titik lebur. Perilaku ini membatasi produksi film kitosan di tingkat komersial dan mempersempit aplikasinya. Pencampuran kitosan dengan termoplastik seperti poli (butilena suksinat), poli (butilentereftalat adipat), poli (butilena suksinat adipat), merupakan alternatif untuk meningkatkan sifat termal bahan ini (Muxika dkk., 2017; Van Den Broek dkk., 2015).

\subsection{Sifat Mekanik}

Studi tentang sifat mekanik seperti kekuatan tarik dan persentase perpanjangan biopolimer yang dikembangkan sebagai film untuk kemasan makanan membantu untuk memprediksi perilaku selama penanganan, penyimpanan dan transport (Campos dkk., 2011). Membandingkan nilai-nilai ini dengan sifat mekanik polimer sintetis komersial yang digunakan membantu untuk memprediksi kesesuaian dan aplikasi masa depan dari biopolimer yang baru (Rouhi dkk., 2017). Sifat mekanik seperti kekuatan tarik, persentase perpanjangan saat putus, gaya tusukan dan deformasi tusukan tergantung pada: komposisi film, sifat komponen, peralatan pengukur dan kondisi pengukuran (kelembaban relatif dan suhu). Sebuah texturometer biasanya digunakan untuk mengukur sifat mekanik dan tusukan film biodegradable.

Kekuatan tarik (MPa) adalah tegangan maksimum yang didukung oleh film sebelum putus. Hal ini mewakili ketahanan terhadap perpanjangan. Persentase perpanjangan saat putus (\%) adalah perpanjangan 


\section{TEKNIK, 42 (3), 2021, 338}

maksimum film sebelum pecah (Miller \& Krochta, 1997; Rouhi dkk., 2017; Spotti dkk., 2016). Biasanya ada hubungan terbalik antara kekuatan tarik dan persentase perpanjangan putus film biopolimer. Perpanjangan film berkurang (persentase perpanjangan putus lebih rendah) ketika: kekuatan film meningkat (kekuatan tarik yang lebih besar) (S. Y. Park dkk., 2002).

Untuk film kitosan murni, ada berbagai sifat mekanik yang dilaporkan data dalam literatur, seperti pada Tabel 1. Menurut penelitian yang dilakukan, variasi tersebut disebabkan oleh perbedaan karakteristik kitosan yang digunakan (derajat deasetilasi, berat molekul), metode pelarut yang digunakan untuk mendapatkan film, waktu penyimpanan, dan kondisi pengukuran sebelum dan selama kinerja tes. Kitosan membentuk ikatan hidrogen antara gugus hidroksil dan gugus amino ke dalam film. Selama pembentukan film, ikatan hidrogen dalam film kitosan meningkat dengan meningkatnya jumlah gugus amino dan hidroksil. Oleh karena itu, berat molekul kitosan mempengaruhi jenis dan jumlah interaksi polimerpolimer dan polimer-pelarut. Kitosan dengan berat molekul tinggi memiliki rantai derajat polimerisasi tinggi, yang mendukung interaksi polimer-polimer, menghasilkan matriks yang kuat dan menurun untuk menurunkan berat molekul. Pada interaksi yang lebih tinggi untuk meningkatkan berat molekul menghasilkan peningkatan gaya tarik kekuatan dan penurunan persentase nilai elongasi, seperti pada Tabel 1 (Bof dkk., 2015; Kerch dan Korkhov, 2011; S. Y. Park dkk., 2002).

Waktu penyimpanan berpengaruh pada sifat mekanik film. Diamati terjadi peningkatan kekuatan tarik, terlepas dari berat molekul. Para penulis dijelaskan oleh perubahan konformasi makromolekul kitosan dan penurunan volume bebas selama penyimpanan. Perubahan konformasi ini dapat bertanggung jawab untuk peningkatan kekuatan tarik (Kerch dan Korkhov, 2011). Mengenai persentase perpanjangan, perilaku sebagai fungsi dari berat molekul, tergantung pada pelarut yang digunakan (S. Y. Park dkk., 2002). Menganalisis sifat mekanik dalam fungsi pelarut yang digunakan, nilai kekuatan tarik yang lebih tinggi diperoleh dengan asam asetat sebagai pelarut. Namun, persentase perpanjangan yang lebih tinggi pada nilai putus diperoleh dengan asam sitrat (Kerch dan Korkhov, 2011; S. Y. Park dkk., 2002). Para penulis menjelaskan bahwa dalam larutan asam asetat, kitosan membentuk dimer, menunjukkan bahwa interaksinya relatif kuat. Hal ini menunjukkan bahwa film kitosan disiapkan dengan asam asetat memiliki struktur yang lebih ketat daripada yang dibuat dengan larutan asam lainnya (K. M. Kim dkk., 2006; S. Y. Park dkk., 2002).

Untuk mendapatkan film tersebut diperlukan langkah pengeringan. Menurut studi yang dilakukan menganalisis tiga metode pengeringan yang berbeda (pengeringan suhu lingkungan, oven pengeringan dan pengeringan inframerah), hasilnya menunjukkan bahwa metode pengeringan yang digunakan tidak secara signifikan mempengaruhi sifat mekanik film (Srinivasa dkk., 2004).

\subsection{Sifat Penghalang}

Sifat penghalang dari film polimer sangat penting untuk memperkirakan atau memprediksi umur simpan produk bila digunakan sebagai kemasan makanan. Salah satu fungsi utama makanan kemasan film adalah untuk

Tabel 1. Sifat mekanik film kitosan murni pada kondisi yang berbeda

\begin{tabular}{|c|c|c|c|c|c|c|}
\hline Komposisi & $\begin{array}{l}\text { Asam yang } \\
\text { digunakan }\end{array}$ & Sifat kitosan & Kondisi & $\begin{array}{c}\text { Kekuatan } \\
\text { tarik }\end{array}$ & Persen elongasi & Referensi \\
\hline Kitosan $2 \%$ & $\begin{array}{l}\text { Asetat } \\
\text { Sitrat } \\
\text { Laktat } \\
\text { Malat }\end{array}$ & $\begin{array}{l}\text { DD 95\% } \\
\text { BM } \\
37-920 \mathrm{kDa}\end{array}$ & $\begin{array}{l}25^{\circ} \mathrm{C} \\
50 \% \mathrm{RH}\end{array}$ & $\begin{array}{l}68,8-50,2 \\
6,7-17,4 \\
17,1-62,6 \\
27,4-62,4\end{array}$ & $\begin{array}{l}7,6-5,5 \\
41,9-117,8 \\
19.6-31.1 \\
17.8-29.9\end{array}$ & (S. Y. Park dkk., 2002) \\
\hline Kitosan $1 \%$ & Asetat & $\mathrm{BM} 150 \mathrm{KDa}$ & $\begin{array}{l}25^{\circ} \mathrm{C} \\
20 \% \mathrm{RH}\end{array}$ & 87,68 & - & (J. Li dkk., 2010) \\
\hline Kitosan $2 \%$ & Asetat & $\begin{array}{l}\text { DD } 80 \% \\
\text { BM } 100 \mathrm{kDa}\end{array}$ & $\begin{array}{l}25^{\circ} \mathrm{C} \\
20 \% \mathrm{RH}\end{array}$ & $49,6-59,4$ & $5,40-8,35$ & (Srinivasa dkk., 2004) \\
\hline Kitosan $2 \%$ & Asetat & $\begin{array}{l}\text { DD } 78 \% \\
\text { BM } 100 \mathrm{kDa}\end{array}$ & - & 55,6 & 8,0 & (Srinivasa dkk., 2003) \\
\hline Kitosan $1 \%$ & Asetat & $\begin{array}{l}\text { DD } 78 \% \\
\text { BM } 200 \mathrm{kDa}\end{array}$ & - & 39,1 & 10,84 & (Srinivasa dkk., 2007) \\
\hline Kitosan $1 \%$ & Asetat & $\mathrm{BM}$ tinggi & $\begin{array}{l}25^{\circ} \mathrm{C} \\
50 \% \mathrm{RH}\end{array}$ & 61,8 & 4,59 & (Leceta dkk., 2013) \\
\hline Kitosan $1 \%$ & Asetat & $\mathrm{BM}$ rendah & $\begin{array}{l}25^{\circ} \mathrm{C} \\
50 \% \mathrm{RH}\end{array}$ & 55,8 & 4,58 & (Leceta dkk., 2013) \\
\hline Kitosan $2,5 \%$ & Asetat & $\begin{array}{l}\text { DD } 85 \% \\
\text { BM rendah }\end{array}$ & $\begin{array}{l}25^{\circ} \mathrm{C} \\
60 \% \mathrm{RH}\end{array}$ & $\sim 10,0$ & $\sim 58,0$ & (Bof dkk., 2015) \\
\hline Kitosan $2,5 \%$ & Asetat & $\begin{array}{l}\text { DD 85\% } \\
\text { BM sedang }\end{array}$ & $\begin{array}{l}25^{\circ} \mathrm{C} \\
60 \% \mathrm{RH}\end{array}$ & $\sim 18,0$ & $\sim 85,0$ & (Bof dkk., 2015) \\
\hline Kitosan $2,5 \%$ & Asetat & $\begin{array}{l}\text { DD 85\% } \\
\text { BM tinggi }\end{array}$ & $\begin{array}{l}25^{\circ} \mathrm{C} \\
60 \% \mathrm{RH}\end{array}$ & $\sim 60,0$ & $\sim 5,0$ & (Bof dkk., 2015) \\
\hline
\end{tabular}

doi: 10.14710/teknik.v42i3.36499

Copyright @ 2021, TEKNIK, p-ISSN: 0852-1697, e-ISSN: 240-9919 


\section{TEKNIK, 42 (3), 2021, 339}

memperlambat transfer molekul antara makanan dan lingkungan, untuk menjaga kualitas makanan. Mengukur sifat-sifat ini memungkinkan untuk mengetahui permeabilitas dan transfer melalui film molekul tertentu seperti gas seperti $\mathrm{O}_{2}$ atau $\mathrm{CO}_{2}$, uap air, uap organik atau cairan. Plastik relatif permeabel untuk molekul. Mereka dapat mentransfer dari lingkungan internal atau eksternal melalui: dinding kemasan polimer, menghasilkan perubahan kualitas produk yang berkelanjutan dan penurunan umur simpan (Aider, 2010; Leceta dkk., 2013; Siracusa dkk., 2008).

Permeabilitas uap air adalah sifat yang paling banyak dipelajari dari film biodegradable. Terutama karena pentingnya peran air dalam memperburuk reaksi, menjaga makanan tetap segar, renyah atau mencegah dehidrasi, tergantung pada makanan dan sebagian karena kemudahan pengukuran.

Di sisi lain, permeabilitas oksigen, nilai yang kurang dipelajari karena peralatan pengukuran diperlukan, tetapi merupakan parameter yang penting. Oksigen terlibat dalam banyak reaksi degradasi dalam makanan, seperti reaksi oksidasi, yang bertanggung jawab untuk perubahan warna, bau, dan rasa makanan, pertumbuhan mikroorganisme, pencoklatan enzimatis dan kehilangan vitamin. Selain itu, permeabilitas terhadap oksigen sangat penting untuk respirasi buah dan sayuran segar. Umumnya, film biopolimer hidrofilik menunjukkan sifat penghalang oksigen yang baik dan permeabilitas uap air yang lebih tinggi (Aider, 2010; Ayranci dan Tunc, 2003; Leceta dkk., 2013; Rao dkk., 2010; Siracusa dkk., 2008).

Film kitosan, seperti banyak film polisakarida lainnya, menunjukkan karakteristik yang relatif rendah terhadap penghalang air karena sifat hidrofiliknya yang tinggi (Aider, 2010; S. I. Park dkk., 2004) seperti yang ditunjukkan pada Tabel 2. Nilai yang dilaporkan dalam literatur harus dibandingkan dengan hati-hati. Nilai permeabilitas uap air tergantung pada sifat film seperti berat molekul, derajat deasetilasi dan kandungan kitosan. Selain itu, nilai-nilai tersebut dipengaruhi oleh berbagai faktor eksternal seperti: metode pengukuran, kondisi pengukuran (kelembaban dan suhu relatif), koreksi efek celah udara, waktu dan kondisi penyimpanan.

Umumnya, berat molekul dan derajat deasetilasi kitosan dan jenis pelarut yang digunakan tidak secara signifikan mempengaruhi nilai permeabilitas uap air dilaporkan (Bof dkk., 2015; Leceta dkk., 2013; S. Y. Park dkk., 2002; Wiles dkk., 2000). Sebaliknya, permeabilitas uap air tergantung pada berat molekul, meningkat ketika berat molekul kitosan yang digunakan meningkat (Kerch \& Korkhov, 2011).

Mengenai permeabilitas oksigen, biasanya ditentukan menurut metode standar ASTM D-3935 (Butler dkk., 1996; PARK dkk., 1993; S. Y. Park dkk., 2002; M. P. Souza dkk., 2015; Vartiainen dkk., 2004). Kurang umum, juga dapat ditentukan menurut metode standar ASTM D-1434 (Srinivasa dkk., 2004). Permeabilitas oksigen dari edible film disebabkan oleh mekanisme kapiler. Permeabilitas oksigen film yang rendah membuatnya ideal untuk digunakan dalam kemasan makanan dan film kitosan menunjukkan sifat penghalang oksigen yang sangat baik. Hal ini adalah nilai yang serupa dengan polivinilidena klorida komersial (PVDC) atau etilena vinil alkohol film kopolimer (S. Y. Park dkk., 2002; Valenzuela dkk., 2013). Faktor seperti berat molekul kitosan, pelarut yang digunakan untuk menyiapkan larutan pembentuk film mempengaruhi permeabilitas oksigen dari film kitosan murni (Leceta dkk., 2013; S. Y. Park dkk., 2002; Valenzuela dkk., 2013).

Tabel 2. Data permeabilitas uap air untuk film kitosan murni pada kondisi yang berbeda

\begin{tabular}{|c|c|c|c|c|c|}
\hline Komposisi & $\begin{array}{l}\text { Asam yang } \\
\text { digunakan }\end{array}$ & Sifat kitosan & Kondisi & $\begin{array}{l}\text { Permeabilitas uap air }(\mathrm{g} / \mathrm{m} \\
\text { s Pa }\end{array}$ & Referensi \\
\hline Kitosan $2 \%$ & $\begin{array}{l}\text { Asetat } \\
\text { Sitrat } \\
\text { Laktat } \\
\text { Malat }\end{array}$ & $\begin{array}{l}\text { DD 95\% } \\
\text { BM } \\
370-920 \mathrm{kDa}\end{array}$ & $\begin{array}{l}25^{\circ} \mathrm{C} \\
50 \% \mathrm{RH}\end{array}$ & $\begin{array}{l}(3,1-3,2) \times 10^{-10} \\
(4,0-5,1) \times 10^{-10} \\
(4,7-6,9) \times 10^{-10} \\
(2,6-4,1) \times 10^{-10}\end{array}$ & (S. Y. Park dkk., 2002) \\
\hline Kitosan $2 \%$ & Asetat & $\begin{array}{l}\text { DD } \sim 80 \% \\
\text { BM } 100 \mathrm{kDa}\end{array}$ & $\begin{array}{l}38^{\circ} \mathrm{C} \\
90 \% \mathrm{RH}\end{array}$ & $(4016-4500) \mathrm{g} / \mathrm{m}^{2}$ day & (Srinivasa dkk., 2004) \\
\hline Kitosan $1 \%$ & Asetat & $\mathrm{BM} \sim 150 \mathrm{kDa}$ & $\begin{array}{l}25^{\circ} \mathrm{C} \\
50 \% \mathrm{RH}\end{array}$ & $3,53 \mathrm{~g} \mathrm{~mm} / \mathrm{m}^{2} \mathrm{~h} \mathrm{kPa}$ & (J. Li dkk., 2010) \\
\hline Kitosan $1 \%$ & Asetat & $\begin{array}{l}\text { DD } 78 \% \\
\text { BM } 100 \mathrm{kDa}\end{array}$ & $90 \% \mathrm{RH}$ & $0,01322 \mathrm{~g} \mathrm{~m} / \mathrm{m}^{2}$ day $\mathrm{kPa}$ & (Srinivasa dkk., 2007) \\
\hline Kitosan $1 \%$ & Asetat & BM tinggi & $\begin{array}{l}38^{\circ} \mathrm{C} \\
90 \% \mathrm{RH}\end{array}$ & $8,07 \times 10^{-13}$ & (Leceta dkk., 2013) \\
\hline Kitosan $1 \%$ & Asetat & $\mathrm{BM}$ rendah & $\begin{array}{l}38^{\circ} \mathrm{C} \\
90 \% \mathrm{RH}\end{array}$ & $8,07 \times 10^{-13}$ & (Leceta dkk., 2013) \\
\hline Kitosan 2,5\% & Asetat & $\begin{array}{l}\text { DD } 85 \% \\
\text { BM rendah }\end{array}$ & $\begin{array}{l}5^{\circ} \mathrm{C} \\
200 \mathrm{~Pa}\end{array}$ & $4,14 \times 10^{-10}$ & (Bof dkk., 2015) \\
\hline Kitosan 2,5\% & Asetat & $\begin{array}{l}\text { DD } 85 \% \\
\text { BM sedang }\end{array}$ & $\begin{array}{l}5^{\circ} \mathrm{C} \\
200 \mathrm{~Pa}\end{array}$ & $3,38 \times 10^{-10}$ & (Bof dkk., 2015) \\
\hline Kitosan $2,5 \%$ & Asetat & $\begin{array}{l}\text { DD } 85 \% \\
\text { BM tinggi }\end{array}$ & $\begin{array}{l}5^{\circ} \mathrm{C} \\
200 \mathrm{~Pa}\end{array}$ & $4,45 \times 10^{-10}$ & (Bof dkk., 2015) \\
\hline
\end{tabular}




\section{TEKNIK, 42 (3), 2021, 340}

Tabel 3. Beberapa kelompok bakteri Gram-negatif, Gram-positif, jamur dan khamir, yang telah digunakan untuk mempelajari efek antimikroba pada film kitosan

\begin{tabular}{lll}
\hline \multicolumn{1}{c}{ Kombinasi kitosan dengan } & \multicolumn{1}{c}{ Mikroorganisme } & \multicolumn{1}{c}{ Referensi } \\
\hline Gram negatif & Escherichia coli & (Helander dkk., 2001) \\
& Photobacterium phosphoreum & (Devlieghere dkk., 2004) \\
& Salmonella enteritidis & (Durango, Soares, Benevides, dkk., 2006) \\
Gram positif & Staphylococcus aureus & (Martínez-Camacho dkk., 2010) \\
& Lactobacillus curvatus & (Devlieghere dkk., 2004) \\
& Bacillus cereus & (Devlieghere dkk., 2004) \\
Ragi & Candida lambica & (Devlieghere dkk., 2004) \\
Jamur & Botrytis cinerea & (Romanazzi dkk., 2002) \\
& Aspergillus niger & (Martínez-Camacho dkk., 2010) \\
\hline
\end{tabular}

\subsection{Sifat Anti Mikroba}

Konsumen menuntut lebih sedikit penggunaan bahan kimia dalam meningkatkan masa kadaluarsa produk makanan. Untuk alasan itu, ada minat yang berkembang belakangan ini untuk mengembangkan material dengan kapasitas pembentuk film dan memiliki sifat antimikroba, yang membantu meningkatkan keamanan pangan dan umur simpan. Penggunaan agen antimikroba yang berasal dari alam semakin meningkatkan perhatian dalam pengembangan bahan kemasan makanan baru sebagai alternatif alami untuk polimer antimikroba yang disintesis secara kimia. Selain itu, agen antimikroba yang berasal dari alam merupakan strategi untuk meningkatkan umur simpan dan mutu bahan pangan, dengan cara menghambat pertumbuhan mikroorganisme pada permukaan makanan, karena kontak dengan film atau pelapis (Moreira dkk., 2011; Van Den Broek dkk., 2015). Kitosan adalah salah satu agen antimikroba yang paling banyak dipelajari untuk kemasan makanan karena sifatnya untuk membentuk film dan pelapis. Kitosan memiliki aktivitas antimikroba terhadap berbagai macam jamur berfilamen bawaan makanan, ragi, dan bakteri, menjadi lebih aktif terhadap ragi (Helander dkk., 2001; H. K. No dkk., 2007).

Selain itu, terdapat faktor intrinsik seperti derajat deasetilasi dan polimerisasi yang mempengaruhi aktivitas antimikroba kitosan. Dalam pengertian ini, aktivitas antimikroba tergantung pada jumlah gugus amino terprotonasi $\left(-\mathrm{NH}_{2}\right)$ yang ada dalam kitosan, yang meningkat ke derajat deasetilasi yang lebih tinggi, karena kelarutan dan kerapatan muatannya yang lebih besar (Elsabee dan Abdou, 2013; Moreira dkk., 2011). Untuk itu, kitosan dengan derajat deasetilasi tinggi $(>85 \%)$ dan berat molekul $28 \mathrm{kDa}$ hingga $1671 \mathrm{kDa}$ telah menunjukkan efek antibakteri terkuat dalam air larutan terlepas dari jenis asam yang digunakan untuk pelarutan (Hong Kyoon No dkk., 2002). Mekanisme yang diusulkan didasarkan pada hasil di mana tindakan dipelajari dengan penambahan mikroorganisme ke dalam media kultur cair atau padat dengan kitosan. Dalam kasus film, mekanisme penghambatan belum dijelaskan. Ada juga faktor eksternal lainnya seperti kondisi anaerobik yang harus dipertimbangkan (Martínez-Camacho dkk., 2010). Selain itu, telah diamati bahwa efek antimikroba tergantung pada komposisi makanan (pati, protein, $\mathrm{NaCl}$, minyak) (Devlieghere dkk., 2004) dan gaya interaksi antara matriks polimer dan senyawa antimikroba, seperti interaksi pati bengkuang-kitosan (Durango, wt al., 2006; Durango, Soares, Benevides, dkk., 2006).

Tabel 3 merangkum beberapa kelompok bakteri gram negatif dan gram positif, jamur dan ragi, yang telah digunakan untuk mempelajari efek antimikroba dari film kitosan.

\subsection{Kombinasi Kitosan dengan Material Lain}

Pencampuran polimer adalah salah satu metode paling efektif untuk mendapatkan material baru yang sesuai dengan keinginan. Dengan mencampurkan kitosan dengan komponen lain yang berbeda sifat mekanik, permeabilitas dan optik memungkinkan untuk mendapatkan sifat film yang disesuaikan dengan aplikasi. Mencampur kitosan dengan senyawa harus memiliki sifat elongasi yang lebih baik, hal ini dimungkinkan untuk memodifikasi permeabilitas uap air hasil film akhir. Biasanya untuk menghasilkan modifikasi permeabilitas uap air diperoleh dari campuran komposit yang ditambahkan dalam matriks kitosan dengan komponen hidrofobik seperti lipid.

Material utama yang digunakan untuk menyempurnakan film berbasis kitosan adalah biasanya material dari bahan alami. Hal ini mempertahankan sifat biodegradabilitas dan dapat dimakan. Pilihan lain yang dipelajari dengan hasil yang baik adalah dengan menambahkan pemlastis biodegradable sintetis untuk memodifikasi sifat mekanik film kitosan.

\subsubsection{Kombinasi Kitosan dengan Pemplastis atau Plasticizer}

Dibandingkan dengan film plastik sintetik, batasan penting film berbahan dasar kitosan adalah sifat mekaniknya, terutama kapasitasnya terhadap sifat kelenturan. Satu dari cara paling umum untuk meningkatkan sifat mekanik film biopolimer adalah menambahkan pemplastis ke dalam formulasi film (Thakhiew dkk., 2015). Pemlastis adalah aditif yang 


\section{TEKNIK, 42 (3), 2021, 341}

digunakan untuk membuat film dengan persentase pemanjangan atau elongasi yang lebih tinggi saat putus dan lebih fleksibel. Beberapa teori telah diajukan untuk menjelaskan mekanisme aksi plastisisasi. Salah satunya berbasis plasticizer yang bisa bertindak sebagai pelumas internal, mengurangi gaya gesekan antara rantai polimer. Teori lain menetapkan bahwa kekakuan polimer berasal dari struktur tiga dimensi di mana pemlastis bekerja dengan memutus interaksi polimer-polimer (misalnya, ikatan hidrogen dan van der Waals atau gaya ionik) (Leceta dkk. 2013).

Kombinasi biopolimer dengan pemlastis dapat dilakukan dengan pencampuran larutan pembentuk film, atau dengan membenamkan film yang dapat terurai secara hayati ke dalam larutan pemplastis (Cazón dkk., 2018). Untuk itu, sebaiknya pemlastis yang ideal larut dan kompatibel dengan kitosan. Jenis pemplastis yang banyak digunakan pada film kitosan adalah poliol seperti gliserol, sorbitol, dan polietilen glikol, gula seperti glukosa dan sukrosa dan lipid (Cazón dkk., 2017; Suyatma dkk., 2005).

Gliserol adalah plasticizer yang paling banyak digunakan dalam polimer biodegradable, terutama di film kitosan. Gliserol dilaporkan dalam formulasi banyak film kitosan di beberapa penelitian, karena kehadiran gliserol memudahkan penanganan film. Di film kitosan, gliserol berpengaruh pada sifat mekanik, mereduksi nilai kekuatan tarik dan meningkatkan persentase perpanjangan putus. Telah dilaporkan variasi dari kekuatan tarik dari 63,1 hingga 22,0 $\mathrm{MPa}$, dan persentase perpanjangan dari 7,2 menjadi $84,2 \%$ untuk menambahkan gliserol ke film kitosan (Suyatma dkk., 2005).

Menganalisis sifat mekanik film kitosan-gliserol, kekuatan tarik dan persentase perpanjangan pada nilai putus film akhir bergantung pada pelarut yang digunakan, sifat kitosan yang digunakan dan kandungan gliserol, seperti ditunjukkan pada Tabel 4 (S. H. Kim dkk., 2007; Ziani dkk., 2008). Selain itu, diamati bahwa Kehadiran gliserol meningkatkan kadar air dalam film, menekankan pada efek plastisisasi gliserol (Ziani dkk., 2008).

Gliserol dibandingkan dengan senyawa hidrofilik lainnya seperti etilen glikol, polietilen glikol, dan propilen glikol sebagai pemlastis untuk kitosan (Kolhe \& Kannan, 2003; Suyatma dkk., 2005) telah diamati bahwa perilaku dan kesesuaian bahan pemlastis tergantung pada konsentrasi. Propilen glikol terwujud perilaku antiplastisisasi pada konsentrasi rendah. Membandingkan hasil yang diperoleh untuk kitosan-pemplastis yang berbeda, pada konsentrasi yang sama, gliserol dan polietilen glikol menunjukkan efisiensi plastisisasi yang lebih tinggi, stabilitas yang lebih baik selama penyimpanan, regangan yang lebih tinggi, dan tegangan tarik yang lebih rendah daripada film yang diplastik oleh propilen glikol. Film dibuat dengan etilen glikol memiliki regangan tinggi dan tegangan rendah sebanding dengan film yang dibuat gliserol dan polietilen glikol. Namun, mereka tidak stabil selama penyimpanan (Suyatma dkk., 2005).

Di sisi lain, pemlastis lain yang banyak digunakan dalam polimer biodegradable adalah polivinil alkohol. Perbedaan utama polivinil alkohol dengan kebanyakan pemlastis adalah bahwa ia merupakan polimer dan memiliki kemampuan untuk membentuk film. Untuk alasan ini, kombinasi polimer dengan polivinil alkohol merupakan campuran dari dua polimer. Polivinil alkohol memanifestasikan efek pemplastis khas pada film kitosan, menurunkan nilai kekuatan tarik dan peningkatan persentase perpanjangan pada nilai putus dengan peningkatan polivinil alkohol (Bonilla dkk., 2014; Srinivasa dkk., 2003). Hal Itu dilaporkan bahwa film kitosan-polivinil alkohol dengan variasi kekuatan tarik 55,56-32,0 MPa, dan persentase perpanjangan putus dari 8 menjadi 70,55\% (Srinivasa dkk., 2003). Pilihan lain untuk meningkatkan sifat mekanik film kitosan adalah dengan menggabungkan mereka dengan beberapa pemlastis secara bersamaan, misalnya; alkohol polivinil

Tabel 4. Sifat mekanik, kuat tarik dan persentase pemanjangan dengan kombinasi yang berbeda dari film berbasis kitosan dengan pemplastis

\begin{tabular}{llllll}
\hline $\begin{array}{c}\text { Kombinasi kitosan } \\
\text { dengan }\end{array}$ & \multicolumn{1}{c}{ Sifat kitosan } & \multicolumn{1}{c}{ Kondisi } & \multicolumn{1}{c}{$\begin{array}{c}\text { Kekuatan tarik } \\
\text { (Mpa) }\end{array}$} & $\begin{array}{c}\text { Persen elongasi } \\
(\%)\end{array}$ & \multicolumn{1}{c}{ Referensi } \\
\hline $\begin{array}{l}\text { Polivinil alkohol } \\
\text { Polietilen oksida }\end{array}$ & BM 150 kDa & BM 150 kDa & $\begin{array}{l}64,8-60,8 \\
62-3,0\end{array}$ & - & (J. Li dkk., 2010) \\
Polivinil alkohol & DD 78 \% & - & $32,0-47,0$ & $26,8-70,6$ & (Srinivasa dkk., 2003) \\
& BM 100 KDa & & & & \\
Gliserol & DD 98 \% & $23{ }^{\circ} \mathrm{C}$ & $31,8-59,5$ & $19,1-84,2$ & (Suyatma dkk., 2005) \\
Etilen glikol & & & $33,2-53,7$ & $16,8-67,0$ & \\
$\begin{array}{l}\text { Polietilen glikol } \\
\text { Propilen glikol }\end{array}$ & & $50 \% \mathrm{RH}$ & $36,6-65,1$ & $12,1-19,7$ & \\
Gliserol & & & $36,3-74,2$ & $6,4-44,3$ & \\
& BM tinggi & $25{ }^{\circ} \mathrm{C}$ & 20,0 & 35,0 & (V. G. L. Souza dkk., \\
Gliserol & & & & & 2017) \\
Gliserol & BM tinggi & $25{ }^{\circ} \mathrm{C}$ & $31,9-43,4$ & $30,5-11,1$ & (Leceta dkk., 2013) \\
\hline
\end{tabular}

doi: 10.14710/teknik.v42i3.36499

Copyright (C) 2021, TEKNIK, p-ISSN: 0852-1697, e-ISSN: 240-9919 


\section{TEKNIK, 42 (3), 2021, 342}

Tabel 5. Sifat mekanik, kekuatan tarik dan persentase pemanjangan dari berbagai kombinasi polisakarida yang berbeda

\begin{tabular}{|c|c|c|c|c|c|}
\hline $\begin{array}{c}\text { Kombinasi kitosan } \\
\text { dengan }\end{array}$ & Sifat kitosan & Kondisi & $\begin{array}{c}\text { Kekuatan } \\
\text { tarik (Mpa) }\end{array}$ & $\begin{array}{c}\text { Persen elongasi } \\
(\%)\end{array}$ & Referensi \\
\hline Selulosa & $\begin{array}{l}\text { DD } 97 \% \\
\text { BM tinggi }\end{array}$ & $\begin{array}{l}25^{\circ} \mathrm{C} \\
50 \% \mathrm{RH}\end{array}$ & $55,0-75,0$ & $6,0-17,0$ & (Fernandes dkk., 2010) \\
\hline Xanthan gum/gliserol & DD $86,3 \%$ & & $9,7-17,0$ & $30,1-23,5$ & (de Morais Lima dkk., 2017) \\
\hline Pati jagung & $\begin{array}{l}\text { DD } 85 \% \\
\text { BM rendah }\end{array}$ & $\begin{array}{l}25^{\circ} \mathrm{C} \\
60 \% \mathrm{RH}\end{array}$ & $17,0-18,0$ & 25,0 & (Bof dkk., 2015) \\
\hline Pati jagung & $\begin{array}{l}\text { DD } 85 \% \\
\text { BM sedang }\end{array}$ & $\begin{array}{l}25^{\circ} \mathrm{C} \\
60 \% \mathrm{RH}\end{array}$ & $5,0-6,0$ & 90,0 & (Bof dkk., 2015) \\
\hline Pati jagung & $\begin{array}{l}\text { DD } 85 \% \\
\text { BM tinggi }\end{array}$ & $\begin{array}{l}25^{\circ} \mathrm{C} \\
60 \% \mathrm{RH}\end{array}$ & $17,0-18,0$ & 18,0 & (Bof dkk., 2015) \\
\hline Tepung pisang/gliserol & $\begin{array}{l}\text { DD } 85 \% \\
\text { BM } 65 \mathrm{kDa}\end{array}$ & $\begin{array}{l}\text { Suhu dan RH } \\
\text { sekeliling }\end{array}$ & $5,2-14,2$ & $1,7-2,6$ & (Pitak dan Rakshit, 2011) \\
\hline Pati jagung/gliserol & DD $90 \%$ & $\begin{array}{l}25^{\circ} \mathrm{C} \\
50 \% \mathrm{RH}\end{array}$ & $26,0-40,0$ & $47,0-62,0$ & (Xu dkk., 2005) \\
\hline $\begin{array}{l}\text { Pati kudzu } \\
\text { Asam laktat }\end{array}$ & $\begin{array}{l}\text { DD } 88,1 \% \\
\text { BM4 } 20 \mathrm{kDa}\end{array}$ & $\begin{array}{l}25^{\circ} \mathrm{C} \\
53 \% \mathrm{RH}\end{array}$ & 5,5 & 82,3 & (Zhong dkk. 2011) \\
\hline Pati buncis/gliserol & BM tinggi & $\begin{array}{l}25^{\circ} \mathrm{C} \\
75 \% \mathrm{RH}\end{array}$ & 9,8 & 29,0 & (Talón dkk., 2017) \\
\hline $\begin{array}{l}\text { Pati singkong/kentang } \\
\text { dengan/tanpa } \\
\text { gliserol/glukosa }\end{array}$ & $\begin{array}{l}\text { DD } 88,1 \% \mathrm{BM} \\
149 \mathrm{kDa}\end{array}$ & $60 \% \mathrm{RH}$ & $8,21-11,68$ & - & (Santacruz dkk., 2015) \\
\hline
\end{tabular}

dengan sorbitol dan sukrosa, menurunkan kekuatan tarik dan meningkatkan persentase perpanjangan (Arvanitoyannis dkk., 1997).

\subsubsection{Kombinasi Kitosan dengan Polisakarida}

Telah dipelajari bagaimana pengaruh kombinasi dan interaksi kitosan dengan polisakarida seperti selulosa, kefiran, pati, xanthan gum, guar gum, dan lainnya. Modifikasi sifat film akibat interaksi antara polisakarida tergantung pada struktur dan sifat intrinsik dari polisakarida yang dipilih (dapat dilihat di Tabel 5).

Selulosa adalah biopolimer yang paling melimpah di bumi, dan asalnya dapat berupa nabati (diisolasi dari kayu dan nabati) atau mikroba (disintesis oleh tunikata dan mikroorganisme). Ketersediaannya yang melimpah menjadikan polisakarida penting untuk upaya pengembangan biopolimer dari kitosan-selulosa. Penambahan selulosa ke dalam matriks kitosan biasanya menghasilkan peningkatan kekakuan, peningkatan kekuatan tarik, dengan konsekuensi penurunan persentase pemanjangan atau elongasi. Efek ini disebabkan oleh penggabungan filler selulosa ke dalam matriks kitosan yang menghasilkan interaksi yang kuat antar senyawa, terutama ikatan hidrogen. Efek penguatan terjadi melalui transfer tegangan yang efektif pada antarmuka selulosa nanofibrilasi / nanowhisker / nanokristalin dan kitosan (Fernandes dkk., 2010; Khan dkk., 2012; Rong dkk., 2017).

Kefiran adalah polisakarida yang larut dalam air dari biji kefir. Film kefiran-kitosan menunjukkan penurunan sifat mekanik bila fraksi kefiran dinaikkan. Hal tersebut menunjukkan bahwa dengan semakin berkurangnya kandungan kitosan maka kemampuan pembentukan ikatan hidrogen antara kitosan dan kefiran semakin menurun, yang memperlemah sifat mekanik lapisan film (Sabaghi dkk., 2015). Dalam kasus pati, interaksi kitosan-pati lebih kompleks, dan modifikasi pada sifat mekanik dan penghalang bergantung pada asal dan struktur (rasio amilosa-amilopektin) pati, sifat kitosan dan pelarut yang digunakan. Hasil evaluasi dari sifat mekanik campuran pati-kitosan, keberadaan pati jagung dalam film kitosan menghasilkan penurunan kuat tarik, tanpa variasi persentase perpanjangan putus. Hal ini dikarenakan nilai ketahanan tegangan pada pati lebih rendah dibandingkan dengan film kitosan murni. Dengan menggabungkan kedua polisakarida, penurunan tegangan ini terjadi. Mengenai persentase pemanjangan, kedua polisakarida dalam film murni memiliki nilai elastisitas yang serupa. Tidak diamati adanya modifikasi fleksibilitas saat menggabungkannya (Bof dkk., 2015; Garcia dkk., 2006).

Dua jenis pati jagung pada film komposit kitosanpati dipelajari untuk mengevaluasi pengaruh struktur pati terhadap sifat mekanik film kitosan: pati biasa dengan amilosa 25\% dan pati lilin dengan 100\% amilopektin. Film komposit dengan kandungan amilosa yang lebih tinggi menunjukkan kekuatan tarik yang lebih tinggi (Xu dkk., 2005). Xanthan gum juga merupakan polisakarida potensial untuk dicampurkan dengan kitosan dalam mengembangkan film yang dapat terurai secara hayati. Xanthan gum dianggap polielektrolit anionik karena gugus karboksilat. Hasil sifat mekanik yang diperoleh menunjukkan bahwa penambahan xanthan gum meningkatkan kekuatan tarik. Namun, hal itu secara signifikan mengurangi persentase perpanjangan. Modifikasi sifat mekanik ini mungkin disebabkan oleh interaksi elektrostatis yang lebih kuat antara polimer- 


\section{TEKNIK, 42 (3), 2021, 343}

polimer, yang mengurangi mobilitas molekul dan meningkatkan kerapuhan (de Morais Lima dkk., 2017). Guar gum menghasilkan peningkatan kekuatan tarik, akibat pembentukan ikatan hidrogen antarmolekul antara $\mathrm{NH}_{3}{ }^{+}$dari tulang punggung $\mathrm{CH}$ dan $\mathrm{OH}$ dari guar gum (Rao dkk., 2010).

\subsubsection{Kombinasi Kitosan dengan Protein}

Kombinasi kitosan dengan protein telah menjadi fokus di banyak penelitian karena potensinya sebagai film yang dapat dimakan. Film ini dapat dibuat dari berbagai bahan untuk mengontrol difusi air dan gas.

Pencampuran dengan protein antara lain gelatin, protein quinoa, protein whey, protein kedelai, dan lainnya. Film yang diperoleh dengan penambahan protein pada kitosan menunjukkan adanya modifikasi pada sifat mekanik, penurunan nilai kekuatan tarik dan peningkatan persentase elongasi pada nilai putus. Tabel 6 menunjukkan beberapa contohnya. Menganalisis beberapa kombinasi material yang telah dilaporkan sebelumnya, gelatin kulit sotong dalam film kitosan menghasilkan penurunan kekuatan tarik dari 59,4 menjadi 45,90 $\mathrm{MPa}$ dan peningkatan persentase elongasi putus dari $1,26 \%$ menjadi 3,96\% (Jridi dkk., 2014), meskipun variasi dalam sifat mekanik sangat sedikit. Gelatin kulit sapi memanifestasikan efek yang sama dari gelatin kulit pada sifat mekanik film kitosan dengan variasi yang lebih signifikan, mulai dari nilai kekuatan tarik 17,34 $\mathrm{MPa}$ untuk film kitosan murni menjadi 6,27 MPa untuk film kitosan-gelatin. Nilai persentase perpanjangan dua kali lipat dari 44,2\% menjadi 85,4\% (Pereda dkk. 2011). Gelatin mempengaruhi persentase pemanjangan saat pecahnya lapisan gelatin-kitosan. Hal itu dikaitkan dengan kandungan asam amino yang berbeda, gelatin kulit sapi memberikan tingkat kekakuan molekuler yang lebih tinggi (Gómez-Estaca dkk., 2010).

Pada film berbasis kitosan yang menggunakan asam laktat sebagai pelarut, penambahan protein quinoa menimbulkan efek plastisisasi, menurunkan nilai kuat tarik dari 22,2 menjadi 2,3 $\mathrm{MPa}$ dan meningkatkan persentase perpanjangan putus dari 73,6 menjadi $237 \%$. Menunjukkan bahwa ikatan hidrogen terjadi selama pembentukan film kitosan ketika dicampur dengan protein quinoa. Interaksi molekuler yang berbeda antara makromolekul ini dibentuk, seperti interaksi ionik dan hidrofobik. Protein juga dapat berinteraksi melalui ikatan disulfida ketika didenaturasi (Abugoch dkk., 2011). Menggunakan asam sitrat sebagai pelarut kitosan, kekuatan tarik menunjukkan nilai yang sama (13,4 hingga 2,7 $\mathrm{MPa}$ ) dengan penambahan protein quinoa, tetapi dengan peningkatan persentase perpanjangan putus yang lebih rendah (20,7 hingga 177,8\%) (Valenzuela dkk., 2013). Penambahan protein whey pada matriks kitosan, juga mengakibatkan penurunan nilai kuat tarik. Tetapi tidak seperti efek yang diamati pada film dengan protein quinoa, ketika menambahkan protein whey terjadi penurunan fleksibilitas film tergantung pada peningkatan jumlah protein (Di Pierro dkk., 2006).

\subsubsection{Kombinasi Kitosan dengan Lipid}

Cara yang mudah untuk meningkatkan sifat fungsional film kitosan untuk memperbesar potensi aplikasinya adalah dengan mencampurkannya dengan minyak esensial. Minyak esensial adalah zat lipid dari tumbuhan, dibentuk oleh terpens, terpenoid, dan senyawa fenolik komponen aromatik dan alifatik lainnya. Sebagian besar minyak esensial ini memiliki sifat antioksidan dan antimikroba yang menarik untuk dikembangkan dalam kemasan makanan aktif. Selain itu karena merupakan komponen hidrofobik, membantu mengurangi permeabilitas uap air film (Hafsa dkk., 2016; Jianglian, 2013; Shen dan Kamdem, 2015). Penggabungan proporsi lipid yang lebih tinggi biasanya menyebabkan perubahan sifat mekanik film, yaitu resistansi dan kekakuan yang lebih rendah (Tabel 7). Secara umum diamati penurunan nilai kekuatan tarik, tetapi perilaku persentase pemanjangan tergantung pada lipid yang ditambahkan dan karakteristik film kitosan.

Terdapat contoh di mana persentase perpanjangan meningkat dan yang lain menurun dengan penambahan

Tabel 6. Sifat mekanik, kekuatan tarik dan persentase perpanjangan, dari kombinasi film kitosan-protein yang berbeda

\begin{tabular}{|c|c|c|c|c|c|}
\hline $\begin{array}{c}\text { Kombinasi kitosan } \\
\text { dengan }\end{array}$ & Sifat kitosan & Kondisi & $\begin{array}{l}\text { Kekuatan tarik } \\
\text { (Mpa) }\end{array}$ & $\begin{array}{c}\text { Persen elongasi } \\
(\%)\end{array}$ & Referensi \\
\hline Protein quinoa & DD $75-80 \%$ & $25^{\circ} \mathrm{C}$ & 2,7 & 177,8 & (Valenzuela dkk., 2013) \\
\hline Asam sitrat & & $60 \% \mathrm{RH}$ & & & \\
\hline $\begin{array}{l}\text { Gelatin kulit } \\
\text { sotong/gliserol }\end{array}$ & DD $88 \%$ & & $59,4-45,9$ & $1,3-4,0$ & (Jridi dkk., 2014) \\
\hline Gelatin/gliserol & DD $90 \%$ & & $17,3-6,3$ & $44,2-85,4$ & (Pereda dkk., 2011) \\
\hline Gelatin kulit tuna & $\begin{array}{l}\text { DD 85 \% } \\
141 \mathrm{kDa}\end{array}$ & & $13,2-20,0$ & $68,2-40,0$ & (Gómez-Estaca dkk., 2011) \\
\hline $\begin{array}{l}\text { Biji-bijian bekas bir/ } \\
\text { gliserin }\end{array}$ & $\begin{array}{l}\text { DD 75\% } \\
\text { BM tinggi }\end{array}$ & $\begin{array}{l}25^{\circ} \mathrm{C} \\
50 \% \mathrm{RH}\end{array}$ & $11,0-26,21$ & $54,6-28,5$ & (J. H. Lee dkk., 2015) \\
\hline Gelatin kulit sapi & $\begin{array}{l}\text { DD } 88 \% \\
141 \mathrm{kDa}\end{array}$ & & $18,4-18,6(\mathrm{~N})$ & $11,0-19,9$ & (Gómez-Estaca dkk., 2011) \\
\hline $\begin{array}{l}\text { Konjak } \\
\text { glukomanan/isolat } \\
\text { protein kedelai }\end{array}$ & DD $85 \%$ & $\begin{array}{l}25^{\circ} \mathrm{C} \\
50 \% \mathrm{RH}\end{array}$ & $16,8-50,4$ & $1,3-7,2$ & (Jia dkk., 2009) \\
\hline
\end{tabular}

doi: 10.14710/teknik.v42i3.36499 


\section{TEKNIK, 42 (3), 2021, 344}

lipid ke matriks kitosan. Efek ini, pada sifat mekanik dikaitkan dengan heterogenitas yang terdapat di struktur film dan adanya efek negatif pada gaya kohesi matriks oleh penggabungan minyak. Berdasarkan pada kajian pustaka, ada beberapa kombinasi dengan minyak esensial dan sumber lipid yang berbeda. Analisis dari beberapa contoh, ekstrak biji anggur pomace tersusun (70\% asam linoleat, $18 \%$ asam oleat, $7 \%$ asam palmitat, dan 5\% asam stearat) ditambahkan ke film kitosan, menghasilkan penurunan daya kekuatan tarik, tetapi tidak ada perbedaan signifikan yang diamati dalam fleksibilitas (Ferreira dkk., 2014).

Film aktif biodegradable dari kitosan yang mengandung minyak esensial citronella dan minyak kayu cedar (10\% sampai 30\% w / w) dikembangkan oleh (Shen dan Kamdem, 2015). Film menunjukkan perubahan yang diharapkan dalam nilai kekuatan tarik. Tetapi persentase permanjangan (persen elongasi) mengalami variasi tergantung pada minyak esensial yang digunakan dan konsentrasi akhir ditambahkan. Namun, kedua minyak esensial tersebut terdapat perilaku yang sama, penurunan efek pemplastis diamati meningkatkan kandungan minyak. Dalam beberapa kasus, efek penambahan minyak esensial meningkatkan sifat antimikroba dan antioksidan kitosan. Misalnya film kitosan yang digabungkan dengan minyak esensial eucalyptus globulus, minyak esensial yang ditambahkan mampu meningkatkan sifat antioksidan dan antimikroba antara lain Escherichia coli, Staphylococcus aureus, Pseudomonas aeruginosa, Candida albicans, Candida parapsilosis (Hafsa dkk., 2016). Kombinasi jahe, rosemari, sage, pohon teh, dan timi minyak atsiri, dengan larutan kitosan-gliserol, hasilnya sifat mekanik menunjukkan perbedaan yang tidak signifikan terhadap kontrol sampel kitosan. Tapi dalam hal ini kemungkinan karena penggabungan Tween 80 sebagai emulsi ke film dengan minyak esensial. Contoh lain dari minyak atsiri yang sifat umumnya ditambahkan ke film kitosan adalah minyak atsiri cengkeh, minyak atsiri Zataria multi flora Boiss, ekstrak biji anggur (M. H. Lee dkk., 2018; Moradi dkk., 2012; V. G. L. Souza dkk., 2017).

Sistem kompleks yang memadukan lebih dari dua komponen seperti protein-kitosan film dengan lipid merupakan strategi untuk menggabungkan sifat yang berbeda dari setiap komponen agar mendapatkan hasil yang lebih baik. Contoh yang dipelajari adalah mencampurkan film kitosan-quinoa protein-minyak biji bunga matahari. Peningkatan minyak bunga matahari menurunkan nilai kekuatan tarik dan persentase perpanjangan.

\subsection{Aplikasi Kitosan sebagai Film atau Pelapis dalam Kemasan Makanan}

Selama beberapa tahun terakhir, minat studi tentang aplikasi potensi kitosan karena film atau lapisan dalam kemasan makanan mengalami peningkatan. Hal ini tidak hanya dikarenakan pembentukan filmnya, sifat antioksidan dan antimikroba, tetapi juga karena sifat mekanis sebagai film. Tujuan dari penelitian tersebut adalah untuk mengembangkan suatu kemasan yang kuat berdasarkan kitosan murni atau dikombinasikan dengan komponen lain dan mengevaluasi potensinya untuk meningkatkan daya simpan makanan yang mudah busuk dan memperpanjang umur simpan. Selain itu, dengan menggabungkan kitosan dengan agen antimikroba alami lainnya, sangat mungkin untuk mendapatkan produk pangan yang menjamin keamanan pangan secara luas dari mikroorganisme (Aider, 2010; Falguera dkk., 2011; H. K. No dkk., 2007; Tharanathan, 2003; Yen dkk., 2008).

Sebagai kemasan makanan yang kuat, kitosan dapat diterapkan untuk makanan sebagai edible film tipis atau edible coating. Edible coating merupakan lapisan tipis yang dibentuk sebagai pelapis pada suatu produk makanan, yang diaplikasikan dalam bentuk cair, dengan mencelupkan produk tersebut ke dalam larutan kitosan, atau dengan semprotan. Sedangkan film kitosan merupakan lapisan tipis yang telah dibentuk sebelumnya, yang setelah terbentuk dapat ditempatkan pada atau di antara komponen makanan (Falguera dkk., 2011; Muxika dkk., 2017).

Pengaplikasian film atau lapisan kitosan semipermeabel menjanjikan untuk meningkatan umur simpan buah dan sayuran yang mudah busuk sebagai perlakuan pasca panen. Sangat mungkin ditemukan dalam literatur, banyak penelitian memaparkan bahwa dengan hasil yang sesuai meningkatkan umur simpan buah pasca panen (El Ghaouth dkk., 1991) dan makanan. Secara keseluruhan, kitosan mengatur pertukaran gas, menghambat tingkat respirasi tingkat produksi etilen yang lebih rendah dibandingkan buah kontrol selama periode penyimpanan (H. Li dan $\mathrm{Yu}, 2001)$. Apalagi sifat anti jamurnya, ia mampu menginduksi respon pertahanan inang, termasuk akumulasi hidrolisat antijamur dan phytoalexin (H. Li dan Yu, 2001). Selain itu, penelitian menunjukkan bahwa dengan menggunakan kitosan terdapat efek yang menguntungkan dalam mempertahankan kekencangan, kadar air, kadar padatan total, dan mempertahankan warna selama penyimpanan pada sayuran dan buah-buahan (P. Chien dan Chou, 2006; Leceta dkk., 2015; H. Li dan Yu, 2001).

Tabel 8 menunjukkan aplikasi film kitosan dalam berbagai produk makanan dan Tabel 9 menunjukkan studi kitosan sebagai pelapis produk makanan. Persik diawetkan dengan lapisan kitosan dan dibandingkan dengan persik yang diolah dengan prokloraz. Hasil penelitian menunjukkan bahwa kitosan mampu mengurangi secara signifikan pembusukan yang disebabkan oleh Monilina fructicola dan Rhizopus stolonifera. Persik yang diberi kitosan lebih kencang dan lebih tinggi keasaman serta vitamin $\mathrm{C}$ nya dibandingkan buah persik yang diberi prokloraz. Selain itu, pelapisan mengurangi pembentukan 


\section{TEKNIK, 42 (3), 2021, 345}

Tabel 7. Sifat mekanik, kekuatan tarik dan persentase perpanjangan, dari kombinasi film kitosan-lipid yang berbeda

\begin{tabular}{|c|c|c|c|c|c|}
\hline $\begin{array}{c}\text { Kombinasi kitosan } \\
\text { dengan }\end{array}$ & Sifat kitosan & Kondisi & $\begin{array}{c}\text { Kekuatan } \\
\text { tarik (Mpa) }\end{array}$ & $\begin{array}{c}\text { Persen elongasi } \\
(\%)\end{array}$ & Referensi \\
\hline $\begin{array}{l}\text { Ekstrak biji anggur / } \\
\text { gliserol }\end{array}$ & $\mathrm{BM} \sim 450 \mathrm{kDa}$ & $52 \% \mathrm{RH}$ & 16,0 & 21,0 & (Moradi dkk., 2012) \\
\hline $\begin{array}{l}\text { Gliserol/tween 80/kayu } \\
\text { manis ( Eo) }\end{array}$ & DD $75-85 \%$ & $\begin{array}{l}25^{\circ} \mathrm{C} 51 \% \\
\mathrm{RH}\end{array}$ & 29,2 & 3,6 & (Ojagh dkk., 2010) \\
\hline Gliserol /cengkeh (Eo) & $\begin{array}{l}\text { DD } 75 \% \\
\text { BM } 190-310 \\
\text { kDa }\end{array}$ & $\begin{array}{l}25^{\circ} \mathrm{C} \\
50 \% \mathrm{RH}\end{array}$ & $\sim 12,0$ & $\sim 22,0$ & (M. H. Lee dkk., 2018) \\
\hline Ekstrak timi/gliserol & $\mathrm{BM}$ tinggi & $\begin{array}{l}25^{\circ} \mathrm{C} \\
50 \% \mathrm{RH}\end{array}$ & 13,0 & 39,0 & (Talón dkk., 2017) \\
\hline Asam tanat / gliserol & $\mathrm{BM}$ tinggi & $\begin{array}{l}25^{\circ} \mathrm{C} \\
50 \% \mathrm{RH}\end{array}$ & 15,0 & 64,0 & (Talón dkk., 2017) \\
\hline $\begin{array}{l}\text { Asam tanat/pati kacang } \\
\text { polong/ekstrak timi /gliserol }\end{array}$ & BM tinggi & $\begin{array}{l}25^{\circ} \mathrm{C} \\
50 \% \mathrm{RH}\end{array}$ & 11,0 & 36,0 & (Talón dkk., 2017) \\
\hline
\end{tabular}

malondialdehida, merangsang aktivitas superoksida dismutase dan menjaga integritas membran $(\mathrm{H}$. Li dan Yu, 2001). Buah klengkeng yang sudah dikupas memiliki umur simpan yang pendek. Dimungkinkan untuk meningkatkan umur simpannya dengan melapisi kitosan. Lapisan kitosan memperlambat penurunan berat dan penurunan kualitas sensorik, menjaga kandungan total padatan terlarut yang lebih tinggi, asam askorbat, serta menekan aktivitas polifenol oksidase dan peroksidase (Dong dkk., 2004). Lapisan kitosan secara efektif meningkatkan segi kualitas dan memperpanjang umur simpan buah mangga yang diiris, memperlambat kehilangan air dan penurunan kualitas sensorik, meningkatkan kandungan padatan terlarut, vitamin $\mathrm{C}$ dan menghambat pertumbuhan mikroorganisme (P. J. Chien, Sheu, \& Lin, 2007; P. J. Chien, Sheu, dan Yang, 2007).

Terkait produk daging, pertumbuhan mikroba umumnya yang paling berperan atas pembusukan daging dan produk daging, terutama pada daging cincang (Devlieghere dkk., 2004). Selain itu, oksigen memiliki efek negatif pada kualitas produk makanan, terutama yang memiliki kandungan lemak tinggi. Kehadiran oksigen menghasilkan kerusakan oksidatif lemak dan minyak, yang menyebabkan bau tengik dan rasa. Hal Ini menurunkan kualitas dan umur simpan produk daging. Film kitosan memiliki sifat penghalang oksigen yang baik. Ini secara efektif melindungi lemak daging dari oksidasi dibandingkan dengan produk daging yang tidak dilindungi. Selain itu, film tersebut efektif dalam mengontrol pertumbuhan mikroba dalam daging. Selanjutnya, penggunaan lapisan kitosan atau film pada produk daging merupakan strategi yang menarik untuk memperpanjang umur simpan daging segar. Kitosan dapat menjadi alternatif penggunaan aditif antimikroba dan antioksidan yang berasal dari sintetik, memberikan nilai tambah pada produk akhir.

\subsection{Tantangan dan Potensi Pemanfaatan Bahan Alam di Indonesia Sebagai Material Bahan Baku untuk Kemasan Plastik Biodegradable}

Indonesia merupakan negara yang kaya akan bahan alam baik tanaman maupun kekayaan lautnya

Tabel 8. Aplikasi film berbasis kitosan dalam berbagai produk makanan

\begin{tabular}{|c|c|c|}
\hline $\begin{array}{c}\text { Film berbasis kitosan dikombinasikan } \\
\text { dengan }\end{array}$ & Makanan & Referensi \\
\hline $\begin{array}{l}\text { Ekstrak gelatin/biji anggur/minyak } \\
\text { esensial Ziziphora clinopodioides }\end{array}$ & Fillet ikan trout cincang & (Moradi dkk., 2011) \\
\hline $\begin{array}{l}\text { Minyak esensial Timus moroderil Timus } \\
\text { piperella }\end{array}$ & Daging ham matang yang dimasak & (Ruiz-Navajas dkk., 2015) \\
\hline $\begin{array}{l}\text { Minyak esensial Zataria } \\
\text { multiflora/Cinnamomum zeylanicum }\end{array}$ & Cabai hijau & (Mohammadi dkk., 2016) \\
\hline Tepung pisang/gliserol & $\begin{array}{l}\text { Asparagus, jagung muda, jamur tiram, kubis } \\
\text { cina }\end{array}$ & (Pitak dan Rakshit, 2011) \\
\hline Gliserol/kulit kacang/lada merah muda & Produk ayam yang direstrukturisasi & (Serrano-León dkk., 2018) \\
\hline $\begin{array}{l}\text { Gelatin/ekstrak biji anggur/minyak } \\
\text { esensial Ziziphora clinopodioides }\end{array}$ & Fillet ikan trout cincang & (Kakaei dan Shahbazi, 2016) \\
\hline Minyak esensial oregano & Irisan bologna & (Chi dkk., 2006) \\
\hline Pati singkong/gliserol/polietilen glikol & Irisan daging babi & (Valencia-Sullca dkk., 2018) \\
\hline $\begin{array}{l}\text { Minyak bunga matahari yang bisa } \\
\text { dimakan }\end{array}$ & Hamburger daging babi & (Vargas dkk., 2011) \\
\hline Lisozim/gliserol & Keju mozarella & (J. Duan dkk., 2007) \\
\hline
\end{tabular}




\section{TEKNIK, 42 (3), 2021, 346}

Tabel 9. Aplikasi pelapis berbahan dasar kitosan pada berbagai produk makanan

\begin{tabular}{lll}
\hline $\begin{array}{l}\text { Kitosan murni atau pelapis berbahan dasar } \\
\text { kitosan dikombinasikan dengan lainnya }\end{array}$ & \multicolumn{1}{c}{ Makanan } & \multicolumn{1}{c}{ Referensi } \\
\hline Kitosan & Strawberi & (Ghaouth dkk. 1991) \\
Kitosan & Tomat & (Ghaouth dkk., 2019) \\
Kitosan & Fillet salmon & (B. W. S. Souza dkk., 2010) \\
Gliserol & Telur & (S. H. Kim dkk., 2007) \\
Kitosan & Jamur & (Eissa, 2007) \\
Asam sitrat/gliserol & Cabai hijau & (Priyadarshi dkk., 2018) \\
Kitosan & Salmon beku & (Soares dkk., 2013) \\
Kitosan & Biji kopi hijau & (Ferreira dkk., 2014) \\
Gliserol & Wortel mini & (Leceta dkk., 2015) \\
Gliserol & Bluberi & (Jingyun Duan dkk., 2011) \\
Tween 80 & Buah pepaya & (Ali dkk., 2011) \\
Kitosan & Buah lengkeng & (Jiang dan Li, 2001) \\
Beeswax/gliserol & Strawberi & (Velickova dkk., 2013) \\
Semperfresh'TM/gliserol/asam stearat & Buah kiwi & (Fisk dkk., 2008) \\
Timi / rosemary & Ikan trout asap & (Doğan dan İzci, 2017) \\
Minyak agar/Artemisia annua & Tomat ceri & (Cui dkk., 2017) \\
Asam asetat/asam laurat/ & Produk daging yang dikemas & (Ouattar dkk., 2000) \\
cinnamaldehid/asam propionat & vakum & \\
Kitosan & Apel & (Choi dkk., 2002; Shao dkk., 2012) \\
Kitosan & Buah mangga & (Djioua dkk., 2010) \\
Minyak esensial hidroksi & Anggur & (Sánchez-González dkk., 2011) \\
propilmetilselulosa/bergamotam & & \\
Asam askorbat/kalsium klorida & Apel 'Fuji' yang baru dipotong & (Qi dkk., 2011) \\
\hline & & \\
& &
\end{tabular}

sangatlah melimpah. Kitosan yang terbuat dari kulit hewan laut crustacea seperti udang dan kepiting sangat melimpah keberadaannya di Indonesia, sehingga ini merupakan potensi yang bisa dimanfaatkan untuk material bahan baku pembuatan plastik biodegradable. Kitosan yang mempunyai sifat anti bakteri sangat cocok untuk pengaplikasian sebagai material untuk kemasan makanan. Tidak hanya itu, kitosan memiliki potensi ekonomi yang sangat tinggi,karena harganya yang terbilang mahal. Jika para pelaku industri laut maupun penduduk pesisir bisa mengolah limbah kulit udang maupun kepiting menjadi kitosan maka akan menambah pendapatan penduduk maupun pelaku usaha dan mensejahterakan rakyat di pesisir. Kitosan sangat popular karena aplikasinya yang sangat luas di dunia riset. Hal ini merupakan salah satu tantangan negara kita yang masih mengimpor kitosan kualitas pro analis dari negara lain dengan harga yang sangat mahal.

Sementara itu, dilihat dari karakteristik negara Indonesia yang merupakan negara agraris maka potensi pemanfaatan bahan baku pati sebagai material plastik biodegradable sangatlah menjanjikan. Sudah banyak penelitian yang meneliti tentang sintesis atau pembuatan plastik biodegradable dari pati singkong, kulit pisang, pati jagung, maupun dari pati jenis tanaman lainnya. Selain karna harganya yang murah, kelimpahan pati di negara agraris seperti di Indonesia sangatlah banyak. Hal ini menjadi tantangan kita sebagai para peneliti maupun pelaku usaha industri kemasan untuk harus bisa memanfaatkan hal ini. Tentu dengan adanya plastik biodegradable, pelan-pelan akan menjaga kelestarian bumi kita terlebih negara kita sendiri. Selain itu juga dapat mengurangi ketergantungan plastik dari minyak bumi yang mana tidak bisa diperbaharui.

\section{Kesimpulan}

Sifat mekanik dan permeabilitas film kitosan murni cocok untuk kemasan makanan dan kemasan aktif. Sifat-sifat ini dapat dimodifikasi dengan menggabungkan kitosan dengan material lain seperti pemplastis, polisakarida, protein dan lipid. Kombinasi ini menyesuaikan sifat-sifat hasil polimer akhir untuk memperpanjang masa simpan makanan, sambil mempertahankan sifat kualitas makanan dan kemampuan terurai secara alami dari polimer tersebut. Kitosan juga menunjukkan aktivitas antimikroba yang baik terhadap berbagai macam jamur makanan, ragi, dan bakteri gram negatif dan gram positif. Sifat antimikroba ini telah menjadikan kitosan sebagai polimer untuk pengembangan kemasan aktif dengan kemampuan menghambat pertumbuhan mikroorganisme serta meningkatkan keamanan pangan.

\section{Ucapan Terima Kasih}

Penulis mengucapkan terima kasih kepada Kementerian Pendidikan, Kebudayaan, Riset, dan Teknologi yang telah memberikan dana penelitian melalui beasiswa Talenta 


\section{TEKNIK, 42 (3), 2021, 347}

Inovasi Indonesia tahun 2021 untuk mahasiswa program magister. Berdasarkan surat perjanjian No: 372.52/E4.4/KU/2021 tanggal: 29 November 2021.

\section{Daftar Pustaka}

Abugoch, L. E., Tapia, C., Villamán, M. C., YazdaniPedram, M., \& Díaz-Dosque, M. (2011). Characterization of quinoa protein-chitosan blend edible films. Food Hydrocolloids. https://doi.org/10.1016/j.foodhyd.2010.08.008

Aider, M. (2010). Chitosan application for active biobased films production and potential in the food industry. LWT-Food Science and Technology, 43(6), 837-842.

Ali, A., Muhammad, M. T. M., Sijam, K., \& Siddiqui, Y. (2011). Effect of chitosan coatings on the physicochemical characteristics of Eksotika II papaya (Carica papaya L.) fruit during cold storage. Food

Chemistry. https://doi.org/10.1016/j.foodchem.2010.06.085

Almeida, E. V. R., Frollini, E., Castellan, A., \& Coma, V. (2010). Chitosan, sisal cellulose, and biocomposite chitosan/sisal cellulose films prepared from thiourea/ $\mathrm{NaOH}$ aqueous solution. Carbohydrate Polymers, $80(3)$. https://doi.org/10.1016/j.carbpol.2009.10.039

Arvanitoyannis, I., Kolokuris, I., Nakayama, A., Yamamoto, N., \& Aiba, S. (1997). Physicochemical studies of chitosan-poly (vinyl alcohol) blends plasticized with sorbitol and sucrose. Carbohydrate Polymers, 34(1-2), 9-19.

Ayranci, E., \& Tunc, S. (2003). A method for the measurement of the oxygen permeability and the development of edible films to reduce the rate of oxidative reactions in fresh foods. Food Chemistry, $80(3)$.

https://doi.org/10.1016/S03088146(02)00485-5

Bof, M. J., Bordagaray, V. C., Locaso, D. E., \& García, M. A. (2015). Chitosan molecular weight effect on starch-composite film properties. Food Hydrocolloids.

https://doi.org/10.1016/j.foodhyd.2015.05.018

Bonilla, J., Fortunati, E., Atarés, L., Chiralt, A., \& Kenny, J. M. (2014). Physical, structural and antimicrobial properties of poly vinyl alcohol-chitosan biodegradable films. Food Hydrocolloids, 35, 463470.

Butler, B. L., Vergano, P. J., Testin, R. F., Bunn, J. M., \& Wiles, J. L. (1996). Mechanical and barrier properties of edible chitosan films as affected by composition and storage. Journal of Food Science, 61(5). $\quad$ https://doi.org/10.1111/j.13652621.1996.tb10909.x
Campos, C. A., Gerschenson, L. N., \& Flores, S. K. (2011). Development of Edible Films and Coatings with Antimicrobial Activity. In Food and Bioprocess Technology (Vol. 4, Issue 6). https://doi.org/10.1007/s11947-010-0434-1

Cazón, P., \& Vázquez, M. (2019). Applications of chitosan as food packaging materials. In Sustainable Agriculture Reviews 36 (pp. 81-123). Springer.

Cazón, P., Vázquez, M., \& Velazquez, G. (2018). Cellulose-glycerol-polyvinyl alcohol composite films for food packaging: Evaluation of water adsorption, mechanical properties, light-barrier properties and transparency. Carbohydrate Polymers, 195, 432-443.

Cazón, P., Velazquez, G., Ramírez, J. A., \& Vázquez, M. (2017). Polysaccharide-based films and coatings for food packaging: A review. Food Hydrocolloids, 68, 136-148.

Chenite, A., Buschmann, M., Wang, D., Chaput, C., \& Kandani, N. (2001). Rheological characterisation of thermogelling chitosan/glycerol-phosphate solutions. Carbohydrate Polymers, 46(1). https://doi.org/10.1016/S0144-8617(00)00281-2

Chi, S., Zivanovic, S., \& Penfield, M. P. (2006). Application of chitosan films enriched with oregano essential oil on bologna - Active compounds and sensory attributes. Food Science and Technology International, 12(2). https://doi.org/10.1177/1082013206063845

Chien, P., \& Chou, C. (2006). Antifungal activity of chitosan and its application to control post- harvest quality and fungal rotting of Tankan citrus fruit (Citrus tankan Hayata). Journal of the Science of Food and Agriculture, 86(12), 1964-1969.

Chien, P. J., Sheu, F., \& Lin, H. R. (2007). Coating citrus (Murcott tangor) fruit with low molecular weight chitosan increases postharvest quality and shelf life. Food Chemistry, 100(3). https://doi.org/10.1016/j.foodchem.2005.10.068

Chien, P. J., Sheu, F., \& Yang, F. H. (2007). Effects of edible chitosan coating on quality and shelf life of sliced mango fruit. Journal of Food Engineering, $78(1)$. https://doi.org/10.1016/j.jfoodeng.2005.09.022

Choi, W. Y., Park, H. J., Ahn, D. J., Lee, J., \& Lee, C. Y. (2002). Wettability of chitosan coating solution on "Fuji" apple skin. Journal of Food Science, 67(7). https://doi.org/10.1111/j.1365-2621.2002.tb08796.x

Cui, H., Yuan, L., Li, W., \& Lin, L. (2017). Edible film incorporated with chitosan and Artemisia annua oil nanoliposomes for inactivation of Escherichia coli O157:H7 on cherry tomato. International Journal of Food Science and Technology, 52(3). https://doi.org/10.1111/ijfs.13322 


\section{TEKNIK, 42 (3), 2021, 348}

de Morais Lima, M., Carneiro, L. C., Bianchini, D., Dias, A. R. G., Zavareze, E. da R., Prentice, C., \& Moreira, A. da S. (2017). Structural, Thermal, Physical, Mechanical, and Barrier Properties of Chitosan Films with the Addition of Xanthan Gum. Journal of Food Science. https://doi.org/10.1111/1750-3841.13653

Devlieghere, F., Vermeulen, A., \& Debevere, J. (2004). Chitosan: Antimicrobial activity, interactions with food components and applicability as a coating on fruit and vegetables. Food Microbiology, 21(6). https://doi.org/10.1016/j.fm.2004.02.008

Di Pierro, P., Chico, B., Villalonga, R., Mariniello, L., Damiao, A. E., Masi, P., \& Porta, R. (2006). Chitosan-whey protein edible films produced in the absence or presence of transglutaminase: Analysis of their mechanical and barrier properties. Biomacromolecules. https://doi.org/10.1021/bm050661u

Djioua, T., Charles, F., Freire, M., Filgueiras, H., Ducamp-Collin, M. N., \& Sallanon, H. (2010). Combined effects of postharvest heat treatment and chitosan coating on quality of fresh-cut mangoes (Mangifera indica L.). International Journal of Food Science and Technology, 45(4). https://doi.org/10.1111/j.1365-2621.2010.02209.x

Doğan, G., \& İzci, L. (2017). Effects on quality properties of smoked rainbow trout (Oncorhynchus mykiss) fillets of chitosan films enriched with essential oils. Journal of Food Processing and Preservation, 41(1). https://doi.org/10.1111/jfpp.12757

Dong, H., Cheng, L., Tan, J., Zheng, K., \& Jiang, Y. (2004). Effects of chitosan coating on quality and shelf life of peeled litchi fruit. Journal of Food Engineering, 64(3). https://doi.org/10.1016/j.jfoodeng.2003.11.003

Duan, J., Park, S. I., Daeschel, M. A., \& Zhao, Y. (2007). Antimicrobial chitosan-lysozyme (CL) films and coatings for enhancing microbial safety of mozzarella cheese. Journal of Food Science, 72(9). https://doi.org/10.1111/j.1750-3841.2007.00556.X

Duan, Jingyun, Wu, R., Strik, B. C., \& Zhao, Y. (2011). Effect of edible coatings on the quality of fresh blueberries (Duke and Elliott) under commercial storage conditions. Postharvest Biology and Technology. https://doi.org/10.1016/j.postharvbio.2010.08.006

Durango, A. M., Soares, N. F. F., \& Andrade, N. J. (2006). Microbiological evaluation of an edible antimicrobial coating on minimally processed carrots. Food Control, 17(5). https://doi.org/10.1016/j.foodcont.2004.10.024

Durango, A. M., Soares, N. F. F., Benevides, S., Teixeira, J., Carvalho, M., Wobeto, C., \& Andrade, N. J. (2006). Development and evaluation of an edible antimicrobial film based on yam starch and chitosan. Packaging Technology and Science, 19(1). https://doi.org/10.1002/pts.713

Eissa, H. A. A. (2007). Effect of chitosan coating on shelf life and quality of fresh-cut mushroom. Journal of Food Quality. https://doi.org/10.1111/j.17454557.2007.00147.x

El Ghaouth, A., Arul, J., Ponnampalam, R., \& Boulet, M. (1991). Chitosan Coating Effect on Storability and Quality of Fresh Strawberries. Journal of Food Science. $\quad$ https://doi.org/10.1111/j.13652621.1991.tb08655.x

Elsabee, M. Z., \& Abdou, E. S. (2013). Chitosan based edible films and coatings: A review. Materials Science and Engineering: C, 33(4), 1819-1841.

Falguera, V., Quintero, J. P., Jiménez, A., Muñoz, J. A., \& Ibarz, A. (2011). Edible films and coatings: Structures, active functions and trends in their use. In Trends in Food Science and Technology (Vol. 22, Issue 6). https://doi.org/10.1016/j.tifs.2011.02.004

Fan, M., \& Hu, Q. (2009). Chitosan-LiOH-urea aqueous solution-a novel water-based system for chitosan processing. Carbohydrate Research, 344(7). https://doi.org/10.1016/j.carres.2009.03.002

Fernandes, S. C. M., Freire, C. S. R., Silvestre, A. J. D., Pascoal Neto, C., Gandini, A., Berglund, L. A., \& Salmén, L. (2010). Transparent chitosan films reinforced with a high content of nanofibrillated cellulose. Carbohydrate Polymers. https://doi.org/10.1016/j.carbpol.2010.02.037

Ferreira, A. S., Nunes, C., Castro, A., Ferreira, P., \& Coimbra, M. A. (2014). Influence of grape pomace extract incorporation on chitosan films properties. Carbohydrate Polymers. https://doi.org/10.1016/j.carbpol.2014.07.032

Fisk, C. L., Silver, A. M., Strik, B. C., \& Zhao, Y. (2008). Postharvest quality of hardy kiwifruit (Actinidia arguta 'Ananasnaya') associated with packaging and storage conditions. Postharvest Biology and Technology, 47(3). https://doi.org/10.1016/j.postharvbio.2007.07.015

Garcia, M. A., Pinotti, A., \& Zaritzky, N. E. (2006). Physicochemical, water vapor barrier and mechanical properties of corn starch and chitosan composite films. Starch/Staerke. https://doi.org/10.1002/star.200500484

Ghaouth, A. El, Ponnampalam, R., Castaigne, F., \& Arul, J. (2019). Chitosan Coating to Extend the Storage Life of Tomatoes. HortScience. https://doi.org/10.21273/hortsci.27.9.1016

Gómez-Estaca, J., Gómez-Guillén, M. C., FernándezMartín, F., \& Montero, P. (2011). Effects of gelatin origin, bovine-hide and tuna-skin, on the properties of compound gelatin-chitosan films. Food 


\section{TEKNIK, 42 (3), 2021, 349}

Hydrocolloids.

https://doi.org/10.1016/j.foodhyd.2011.01.007

Gómez-Estaca, J., López de Lacey, A., López-Caballero, M. E., Gómez-Guillén, M. C., \& Montero, P. (2010). Biodegradable gelatin-chitosan films incorporated with essential oils as antimicrobial agents for fish preservation. Food Microbiology. https://doi.org/10.1016/j.fm.2010.05.012

Hafsa, J., Smach, M. ali, Ben Khedher, M. R., Charfeddine, B., Limem, K., Majdoub, H., \& Rouatbi, S. (2016). Physical, antioxidant and antimicrobial properties of chitosan films containing Eucalyptus globulus essential oil. $L W T$ Food Science and Technology. https://doi.org/10.1016/j.lwt.2015.12.050

Helander, I. M., Nurmiaho-Lassila, E. L., Ahvenainen, R., Rhoades, J., \& Roller, S. (2001). Chitosan disrupts the barrier properties of the outer membrane of Gram-negative bacteria. International Journal of Food Microbiology, 71(2-3). https://doi.org/10.1016/S0168-1605(01)00609-2

Jia, D., Fang, Y., \& Yao, K. (2009). Water vapor barrier and mechanical properties of konjac glucomannanchitosan-soy protein isolate edible films. Food and Bioproducts Processing, 87(1). https://doi.org/10.1016/j.fbp.2008.06.002

Jiang, Y., \& Li, Y. (2001). Effects of chitosan coating on postharvest life and quality of longan fruit. Food Chemistry, 73(2). https://doi.org/10.1016/S03088146(00)00246-6

Jianglian, D. (2013). Application of Chitosan Based Coating in Fruit and Vegetable Preservation: A Review. Journal of Food Processing \& Technology. $\quad$ https://doi.org/10.4172/21577110.1000227

Jridi, M., Hajji, S., Ayed, H. Ben, Lassoued, I., Mbarek, A., Kammoun, M., Souissi, N., \& Nasri, M. (2014). Physical, structural, antioxidant and antimicrobial properties of gelatin-chitosan composite edible films. International Journal of Biological Macromolecules. https://doi.org/10.1016/j.ijbiomac.2014.03.054

Kakaei, S., \& Shahbazi, Y. (2016). Effect of chitosangelatin film incorporated with ethanolic red grape seed extract and Ziziphora clinopodioides essential oil on survival of Listeria monocytogenes and chemical, microbial and sensory properties of minced trout fillet. LWT - Food Science and Technology, https://doi.org/10.1016/j.lwt.2016.05.021

Kerch, G., \& Korkhov, V. (2011). Effect of storage time and temperature on structure, mechanical and barrier properties of chitosan-based films. European Food Research and Technology, 232(1), $17-22$.
Khan, A., Khan, R. A., Salmieri, S., Le Tien, C., Riedl, B., Bouchard, J., Chauve, G., Tan, V., Kamal, M. R., \& Lacroix, M. (2012). Mechanical and barrier properties of nanocrystalline cellulose reinforced chitosan based nanocomposite films. Carbohydrate Polymers. https://doi.org/10.1016/j.carbpol.2012.07.037

Kim, K. M., Son, J. H., Kim, S., Weller, C. L., \& Hanna, M. A. (2006). Properties of chitosan films as a function of $\mathrm{pH}$ and solvent type. Journal of Food Science, 71(3), E119-E124.

Kim, S. H., No, H. K., \& Prinyawiwatkul, W. (2007). Effect of molecular weight, type of chitosan, and chitosan solution $\mathrm{pH}$ on the shelf- life and quality of coated eggs. Journal of Food Science, 72(1), S044-S048.

Kolhe, P., \& Kannan, R. M. (2003). Improvement in ductility of chitosan through blending and copolymerization with PEG: FTIR investigation of molecular interactions. Biomacromolecules, 4(1), 173-180.

Leceta, I., Guerrero, P., \& De La Caba, K. (2013). Functional properties of chitosan-based films. Carbohydrate Polymers, 93(1), 339-346.

Leceta, I., Molinaro, S., Guerrero, P., Kerry, J. P., \& De la Caba, K. (2015). Quality attributes of map packaged ready-to-eat baby carrots by using chitosan-based coatings. Postharvest Biology and Technology. https://doi.org/10.1016/j.postharvbio.2014.09.022

Lee, J. H., Lee, J. H., Yang, H. J., \& Song, K. Bin. (2015). Preparation and characterization of brewer's spent grain protein-chitosan composite films. Journal of Food Science and Technology, 52(11). https://doi.org/10.1007/s13197-015-1941-x

Lee, M. H., Kim, S. Y., \& Park, H. J. (2018). Effect of halloysite nanoclay on the physical, mechanical, and antioxidant properties of chitosan films incorporated with clove essential oil. Food Hydrocolloids. https://doi.org/10.1016/j.foodhyd.2018.05.048

Li, H., \& Yu, T. (2001). Effect of chitosan on incidence of brown rot, quality and physiological attributes of postharvest peach fruit. Journal of the Science of Food and Agriculture, 81(2), 269-274.

Li, J., Zivanovic, S., Davidson, P. M., \& Kit, K. (2010). Characterization and comparison of chitosan/PVP and chitosan/PEO blend films. Carbohydrate Polymers. https://doi.org/10.1016/j.carbpol.2009.09.028

Martínez-Camacho, A. P., Cortez-Rocha, M. O., Ezquerra-Brauer, J. M., Graciano-Verdugo, A. Z., Rodriguez-Félix, F., Castillo-Ortega, M. M., YépizGómez, M. S., \& Plascencia-Jatomea, M. (2010). Chitosan composite films: Thermal, structural, 


\section{TEKNIK, 42 (3), 2021, 350}

mechanical and antifungal properties. Carbohydrate Polymers, $82(2)$. https://doi.org/10.1016/j.carbpol.2010.04.069

Miller, K. S., \& Krochta, J. M. (1997). Oxygen and aroma barrier properties of edible films: A review. In Trends in Food Science and Technology (Vol. 8, Issue 7). https://doi.org/10.1016/S09242244(97)01051-0

Mohammadi, A., Hashemi, M., \& Hosseini, S. M. (2016). Postharvest treatment of nanochitosan-based coating loaded with Zataria multiflora essential oil improves antioxidant activity and extends shelf-life of cucumber. Innovative Food Science and Emerging https://doi.org/10.1016/j.ifset.2015.10.015

Moradi, M., Tajik, H., Razavi Rohani, S. M., \& Oromiehie, A. R. (2011). Effectiveness of Zataria multiflora Boiss essential oil and grape seed extract impregnated chitosan film on ready-to-eat mortadella-type sausages during refrigerated storage. Journal of the Science of Food and Agriculture, 91(15). https://doi.org/10.1002/jsfa.4531

Moradi, M., Tajik, H., Razavi Rohani, S. M., Oromiehie, A. R., Malekinejad, H., Aliakbarlu, J., \& Hadian, M. (2012). Characterization of antioxidant chitosan film incorporated with Zataria multiflora Boiss essential oil and grape seed extract. LWT - Food Science and Technology. https://doi.org/10.1016/j.lwt.2011.11.020

Moreira, M. del R., Roura, S. I., \& Ponce, A. (2011). Effectiveness of chitosan edible coatings to improve microbiological and sensory quality of fresh cut broccoli. LWT - Food Science and Technology, 44(10). https://doi.org/10.1016/j.lwt.2011.04.009

Morgado, D. L., Frollini, E., Castellan, A., Rosa, D. S., \& Coma, V. (2011). Biobased films prepared from $\mathrm{NaOH} /$ thiourea aqueous solution of chitosan and linter cellulose. Cellulose, 18(3). https://doi.org/10.1007/s10570-011-9516-0

Muxika, A., Etxabide, A., Uranga, J., Guerrero, P., \& de la Caba, K. (2017). Chitosan as a bioactive polymer: Processing, properties and applications. In International Journal of Biological Macromolecules (Vol. 105). https://doi.org/10.1016/j.ijbiomac.2017.07.087

No, H. K., Meyers, S. P., Prinyawiwatkul, W., \& Xu, Z. (2007). Applications of chitosan for improvement of quality and shelf life of foods: A review. In Journal of Food Science (Vol. 72, Issue 5). https://doi.org/10.1111/j.1750-3841.2007.00383.x

No, Hong Kyoon, Young Park, N., Ho Lee, S., \& Meyers, S. P. (2002). Antibacterial activity of chitosans and chitosan oligomers with different molecular weights. International Journal of Food
Microbiology,

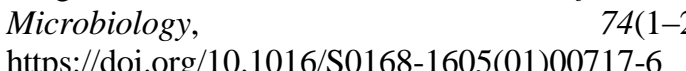

Ojagh, S. M., Rezaei, M., Razavi, S. H., \& Hosseini, S. M. H. (2010). Development and evaluation of a novel biodegradable film made from chitosan and cinnamon essential oil with low affinity toward water. Food Chemistry. https://doi.org/10.1016/j.foodchem.2010.02.033

Ouattar, B., Simard, R. E., Piett, G., Bégin, A., \& Holley, R. A. (2000). Inhibition of surface spoilage bacteria in processed meats by application of antimicrobial films prepared with chitosan. International Journal of Food Microbiology, 62(1-2). https://doi.org/10.1016/S0168-1605(00)00407-4

Park, H. J., Weller, C. L., Vergano, P. J., \& Testin, R. F. (1993). Permeability and Mechanical Properties of Cellulose- Based Edible Films. Journal of Food Science, 58(6). https://doi.org/10.1111/j.13652621.1993.tb06183.x

Park, S. I., Daeschel, M. A., \& Zhao, Y. (2004). Functional properties of antimicrobial lysozymechitosan composite films. Journal of Food Science, 69(8). https://doi.org/10.1111/j.13652621.2004.tb09890.x

Park, S. Y., Marsh, K. S., \& Rhim, J. W. (2002). Characteristics of different molecular weight chitosan films affected by the type of organic solvents. Journal of Food Science, 67(1). https://doi.org/10.1111/j.1365-2621.2002.tb11382.x

Pereda, M., Ponce, A. G., Marcovich, N. E., Ruseckaite, R. A., \& Martucci, J. F. (2011). Chitosan-gelatin composites and bi-layer films with potential antimicrobial activity. Food Hydrocolloids. https://doi.org/10.1016/j.foodhyd.2011.01.001

Pitak, N., \& Rakshit, S. K. (2011). Physical and antimicrobial properties of banana flour/chitosan biodegradable and self sealing films used for preserving Fresh-cut vegetables. LWT-Food Science and Technology, 44(10), 2310-2315.

Priyadarshi, R., Sauraj, Kumar, B., \& Negi, Y. S. (2018). Chitosan film incorporated with citric acid and glycerol as an active packaging material for extension of green chilli shelf life. Carbohydrate Polymers. https://doi.org/10.1016/j.carbpol.2018.04.089

Qi, H., Hu, W., Jiang, A., Tian, M., \& Li, Y. (2011). Extending shelf-life of Fresh-cut "Fuji" apples with chitosan-coatings. Innovative Food Science and Emerging Technologies, 12(1). https://doi.org/10.1016/j.ifset.2010.11.001

Rao, M. S., Kanatt, S. R., Chawla, S. P., \& Sharma, A. (2010). Chitosan and guar gum composite films: Preparation, physical, mechanical and antimicrobial properties. Carbohydrate Polymers. 


\section{TEKNIK, 42 (3), 2021, 351}

https://doi.org/10.1016/j.carbpol.2010.06.058

Rinaudo, M. (2006). Chitin and chitosan: Properties and applications. Progress in Polymer Science, 31(7), 603-632.

Romanazzi, G., Nigro, F., Ippolito, A., DiVenere, D., \& Salerno, M. (2002). Effects of pre- and postharvest chitosan treatments to control storage grey mold of table grapes. Journal of Food Science, 67(5). https://doi.org/10.1111/j.1365-2621.2002.tb08737.x

Rong, S. Y., Mubarak, N. M., \& Tanjung, F. A. (2017). Structure-property relationship of cellulose nanowhiskers reinforced chitosan biocomposite films. Journal of Environmental Chemical Engineering. https://doi.org/10.1016/j.jece.2017.11.054

Rouhi, M., Razavi, S. H., \& Mousavi, S. M. (2017). Optimization of crosslinked poly(vinyl alcohol) nanocomposite films for mechanical properties. Materials Science and Engineering C, 71. https://doi.org/10.1016/j.msec.2016.11.135

Ruiz-Navajas, Y., Viuda-Martos, M., Barber, X., Sendra, E., Perez-Alvarez, J. A., \& Fernández-López, J. (2015). Effect of chitosan edible films added with Thymus moroderi and Thymus piperella essential oil on shelf-life of cooked cured ham. Journal of Food Science and Technology. https://doi.org/10.1007/s13197-015-1733-3

Sabaghi, M., Maghsoudlou, Y., \& Habibi, P. (2015). Enhancing structural properties and antioxidant activity of kefiran films by chitosan addition. Food Structure.

https://doi.org/10.1016/j.foostr.2015.06.003

Sánchez-González, L., Chiralt, A., González-Martínez, C., \& Cháfer, M. (2011). Effect of essential oils on properties of film forming emulsions and films based on hydroxypropylmethylcellulose and chitosan. Journal of Food Engineering, 105(2). https://doi.org/10.1016/j.jfoodeng.2011.02.028

Santacruz, S., Rivadeneira, C., \& Castro, M. (2015). Edible films based on starch and chitosan. Effect of starch source andconcentration, plasticizer, surfactant's hydrophobic tail andmechanical treatment. Food Hydrocolloids, 49. https://doi.org/10.1016/j.foodhyd.2015.03.019

Serrano-León, J. S., Bergamaschi, K. B., Yoshida, C. M. P., Saldaña, E., Selani, M. M., Rios-Mera, J. D., Alencar, S. M., \& Contreras-Castillo, C. J. (2018). Chitosan active films containing agro-industrial residue extracts for shelf life extension of chicken restructured product. Food Research International. https://doi.org/10.1016/j.foodres.2018.03.031

Shao, X. F., Tu, K., Tu, S., \& Tu, J. (2012). A Combination of heat treatment and chitosan coating delays ripening and reduces decay in "gala" apple fruit. Journal of Food Quality, 35(2). https://doi.org/10.1111/j.1745-4557.2011.00429.x

Shen, Z., \& Kamdem, D. P. (2015). Development and characterization of biodegradable chitosan films containing two essential oils. International Journal of Biological Macromolecules. https://doi.org/10.1016/j.ijbiomac.2014.11.046

Siracusa, V., Rocculi, P., Romani, S., \& Rosa, M. D. (2008). Biodegradable polymers for food packaging: a review. In Trends in Food Science and Technology (Vol. 19, Issue 12). https://doi.org/10.1016/j.tifs.2008.07.003

Soares, N. M., Mendes, T. S., \& Vicente, A. A. (2013). Effect of chitosan-based solutions applied as edible coatings and water glazing on frozen salmon preservation - A pilot-scale study. Journal of Food Engineering. https://doi.org/10.1016/j.jfoodeng.2013.05.018

Souza, B. W. S., Cerqueira, M. A., Ruiz, H. A., Martins, J. T., Casariego, A., Teixeira, J. A., \& Vicente, A. A. (2010). Effect of Chitosan-based coatings on the shelf life of Salmon (Salmo salar). Journal of Agricultural and Food Chemistry. https://doi.org/10.1021/jf102366k

Souza, M. P., Vaz, A. F. M., Silva, H. D., Cerqueira, M. A., Vicente, A. A., \& Carneiro-da-Cunha, M. G. (2015). Development and Characterization of an Active Chitosan-Based Film Containing Quercetin. Food and Bioprocess Technology, 8(11). https://doi.org/10.1007/s11947-015-1580-2

Souza, V. G. L., Fernando, A. L., Pires, J. R. A., Rodrigues, P. F., Lopes, A. A. S., \& Fernandes, F. M. B. (2017). Physical properties of chitosan films incorporated with natural antioxidants. Industrial Crops and Products. https://doi.org/10.1016/j.indcrop.2017.04.056

Spotti, M. L., Cecchini, J. P., Spotti, M. J., \& Carrara, C. R. (2016). Brea Gum (from Cercidium praecox) as a structural support for emulsion-based edible films. LWT - Food Science and Technology, 68. https://doi.org/10.1016/j.lwt.2015.12.018

Srinivasa, P. C., Ramesh, M. N., Kumar, K. R., \& Tharanathan, R. N. (2003). Properties and sorption studies of chitosan-polyvinyl alcohol blend films. Carbohydrate Polymers, 53(4), 431-438.

Srinivasa, P. C., Ramesh, M. N., Kumar, K. R., \& Tharanathan, R. N. (2004). Properties of chitosan films prepared under different drying conditions. Journal of Food Engineering, 63(1). https://doi.org/10.1016/S0260-8774(03)00285-1

Srinivasa, P. C., Ramesh, M. N., \& Tharanathan, R. N. (2007). Effect of plasticizers and fatty acids on mechanical and permeability characteristics of chitosan films. Food Hydrocolloids, 21(7), 11131122.

Suyatma, N. E., Tighzert, L., Copinet, A., \& Coma, V. 


\section{TEKNIK, 42 (3), 2021, 352}

(2005). Effects of hydrophilic plasticizers on mechanical, thermal, and surface properties of chitosan films. Journal of Agricultural and Food Chemistry, 53(10), 3950-3957.

Talón, E., Trifkovic, K. T., Nedovic, V. A., Bugarski, B. M., Vargas, M., Chiralt, A., \& González-Martínez, C. (2017). Antioxidant edible films based on chitosan and starch containing polyphenols from thyme extracts. Carbohydrate Polymers. https://doi.org/10.1016/j.carbpol.2016.10.080

Thakhiew, W., Champahom, M., Devahastin, S., \& Soponronnarit, S. (2015). Improvement of mechanical properties of chitosan-based films via physical treatment of film-forming solution. Journal of Food Engineering, 158, 66-72.

Tharanathan, R. N. (2003). Biodegradable films and composite coatings: Past, present and future. In Trends in Food Science and Technology (Vol. 14, Issue 3). https://doi.org/10.1016/S09242244(02)00280-7

Valencia-Sullca, C., Atarés, L., Vargas, M., \& Chiralt, A. (2018). Physical and Antimicrobial Properties of Compression-Molded Cassava Starch-Chitosan Films for Meat Preservation. Food and Bioprocess Technology, 11(7). https://doi.org/10.1007/s11947018-2094-5

Valenzuela, C., Abugoch, L., \& Tapia, C. (2013). Quinoa protein-chitosan-sunflower oil edible film: Mechanical, barrier and structural properties. $L W T$ Food Science and Technology. https://doi.org/10.1016/j.lwt.2012.08.010

Van Den Broek, L. A. M., Knoop, R. J. I., Kappen, F. H. J., \& Boeriu, C. G. (2015). Chitosan films and blends for packaging material. Carbohydrate Polymers, 116. https://doi.org/10.1016/j.carbpol.2014.07.039

Vargas, M., Albors, A., \& Chiralt, A. (2011). Application of chitosan-sunflower oil edible films to pork meat hamburgers. Procedia Food Science, 1. https://doi.org/10.1016/j.profoo.2011.09.007

Vartiainen, J., Motion, R., Kulonen, H., Rättö, M., Skyttä, E., \& Ahvenainen, R. (2004). Chitosan-coated paper: Effects of nisin and different acids on the antimicrobial activity. Journal of Applied Polymer
Science, 94(3). https://doi.org/10.1002/app.20701

Velickova, E., Winkelhausen, E., Kuzmanova, S., Alves, V. D., \& Moldão-Martins, M. (2013). Impact of chitosan-beeswax edible coatings on the quality of fresh strawberries (Fragaria ananassa cv Camarosa) under commercial storage conditions. LWT - Food Science and Technology, 52(2). https://doi.org/10.1016/j.lwt.2013.02.004

Wiles, J. L., Vergano, P. J., Barron, F. H., Bunn, J. M., \& Testin, R. F. (2000). Water vapor transmission rates and sorption behavior of chitosan films. Journal of Food Science, 65(7). https://doi.org/10.1111/j.13652621.2000.tb10261.x

Xu, Y. X., Kim, K. M., Hanna, M. A., \& Nag, D. (2005). Chitosan-starch composite film: Preparation and characterization. Industrial Crops and Products. https://doi.org/10.1016/j.indcrop.2004.03.002

Yen, M. T., Yang, J. H., \& Mau, J. L. (2008). Antioxidant properties of chitosan from crab shells. Carbohydrate Polymers, 74(4). https://doi.org/10.1016/j.carbpol.2008.05.003

Zhang, L., Mao, Y., Zhou, J., \& Cai, J. (2005). Effects of coagulation conditions on the properties of regenerated cellulose films prepared in $\mathrm{NaOH} / \mathrm{Urea}$ aqueous solution. Industrial and Engineering Chemistry Research, 44(3). https://doi.org/10.1021/ie0491802

Zhang, W., \& Xia, W. (2014). Dissolution and stability of chitosan in a sodium hydroxide/urea aqueous solution. Journal of Applied Polymer Science, 131(3). https://doi.org/10.1002/app.39819

Zhong, Y., Song, X., \& Li, Y. (2011). Antimicrobial, physical and mechanical properties of kudzu starchchitosan composite films as a function of acid solvent types. Carbohydrate Polymers. https://doi.org/10.1016/j.carbpol.2010.11.041

Ziani, K., Oses, J., Coma, V., \& Maté, J. I. (2008). Effect of the presence of glycerol and Tween 20 on the chemical and physical properties of films based on chitosan with different degree of deacetylation. LWT-Food Science and Technology, 41(10), 21592165. 